\title{
Analysis of some species resembling Fragilaria capucina (Fragilariaceae, Bacillariophyta)
}

\author{
Bart Van De ViJver ${ }^{1,2}$, David M. Williams ${ }^{3}$, Martyn Kelly ${ }^{4}$, Amelie Jarlman ${ }^{5}$, \\ Carlos E. WeTZEL ${ }^{6} \&$ Luc ECTOR $^{6}$
}

\author{
${ }^{1}$ Meise Botanic Garden, Research Department, Nieuwelaan 38, 1860 Meise, Belgium; *corresponding author: \\ bart.vandevijver@plantentuinmeise.be \\ ${ }^{2}$ University of Antwerp, Department of Biology - ECOBE, Universiteitsplein 1, 2610 Wilrijk, Belgium \\ ${ }^{3}$ The Natural History Museum, Department of Life Sciences, Cromwell Road, London, SW7 5BD, UK \\ ${ }^{4}$ Bowburn Consultancy, 11 Monteigne Drive, Bowburn, Durham DH65QB, United Kingdom \\ ${ }^{5}$ Jarlman Konsult, Lilla Gråbrödersgatan 2 B, 22222 Lund, Sweden \\ ${ }^{6}$ Luxembourg Institute of Science and Technology (LIST), Environmental Research \& Innovation (ERIN) \\ Department, 41 rue du Brill, 4422 Belvaux, Luxembourg
}

\begin{abstract}
Based on literature data, Fragilaria capucina seems to be a widespread species, often split into a large number of varieties. In the present study, the original type material was investigated, together with the type material of two varieties, originally described by Grunow as the var. acuta and the var. acuminata and the type material of Fragilaria sandellii and F. nevadensis. The results of all morphological analyses indicated that $F$. capucina is clearly different from the other species based on the number of rimoportulae, valve outline and spine morphology. The var. acuta and var. acuminata are conspecific with F. nevadensis and are added as synonyms of the latter. Additionally, three unidentified populations from Sweden and the United Kingdom that showed some resemblance to F. capucina were analysed. Using detailed LM and SEM observations, these three populations showed sufficient morphological differences from all other Fragilaria species and are therefore described as new for science: F. malouana Van de Vijver et Jarlman nov. sp., F. battarbeeana Van de Vijver, M.Kelly, C.E. Wetzel et Ector nov. sp. and F. ennerdalensis Van de Vijver, M.Kelly, C.E.Wetzel et Ector nov. sp.
\end{abstract}

Key words: Fragilaria, colony-forming, new species, morphology, Europe

\section{INTRODUCTION}

Fragilaria capucina Desmazières was originally described in 1830 from France in the Plantes Cryptogames du nord de la France (Desmazières 1830, no. 453, see also DesmaZiÈres 1831, p. 200, tab. 4, fig. [icon.] 3), part of the $1^{\text {st }}$ edition of an exsiccatae assembled by Desmazières from 1825 to 1851 (Desmazières 1825-1851). Since its description, Fragilaria capucina was often reported in the literature of the nineteenth century (e.g., SMITH 1856; O'Meara 1875; Van Heurck 1882-1885). Hustedt (1931, p. 144) listed a long series of presumed synonyms but separated out three varieties (acuta, mesolepta and lanceolata) based on observations derived from Grunow (in VAN HEURCK 1881) and RABENHORST (1861). Although the morphology of Fragilaria capucina has been well documented after the publication of several valves from the type material in Krammer \& LANGE-BERTALOT (1991, plate 108 , figs $\left.1-8^{1}\right)$, the species has often been incorrectly identified, most likely due to taxonomic drift and the force-fitting of many populations from all over the world into F. capucina.

Subsequent confusion may be due to the adoption of the broad species concept in LANGE-BERTALOT (1980), resulting in the combination of many taxa first described in Fragilaria (and some formerly part of Synedra) as varieties of $F$. capucina (e.g., F. capucina var. vaucheriae (Kützing) Lange-Bertalot, F. capucina var. austriaca (Grunow) Lange-Bertalot). Krammer \& LANGE-Bertalot (1991) continued this approach with the addition of F. capucina var. rumpens (Kützing) Lange-Bertalot

1 In his 1980 paper on Fragilaria, Lange-Bertalot discussed Fragilaria capucina at length and proposed some synonyms. In the reprints distributed by the author a sheet of images from type specimens was included. 
and $F$. capucina var. amphicephala (Grunow) LangeBertalot. They also stated that $F$. capucina forms both long, ribbon-colonies (which they called 'fragilarioid') and 'pincushion' aggregates ('synedroid'). Together with the broad range in length $(10-100 \mu \mathrm{m})$ and width $(2-6.5 \mu \mathrm{m})$ and a very generalized description of the valve outline, ranging from linear to broadly lanceolate with non-protracted to even weakly capitate apices, the original concept of the taxon became a classic example of taxonomic drift. In the second edition of KRAMMER \& LANGE-BERTALOT (2000), this practice of recombining all taxa as $F$. capucina varieties, was reversed and several of these (often originally Synedra) taxa were recombined as independent species: Fragilaria austriaca (Grunow) Lange-Bertalot, F. perminuta (Grunow) Lange-Bertalot and $F$. radians (Kützing) Lange-Bertalot.

TUJi \& Williams (2006a) later analysed the history of the original Desmazières material, concluding that the actual publication date for $F$. capucina was 1830 (see SAYRE 1969, p. 12). They also performed an extensive analysis (including some SEM observations) of the Fragilaria specimens recorded in the type material, reinstating the original description of the taxon. A lectotype specimen on a glass slide (BM 81302) is housed in the Natural History Museum, London (BM, TuJi \& Williams 2006a, p. 198).

Despite taxonomic and morphological revisions of the group of taxa, formerly combined with $F$. capucina, often based on a reanalysis of original type material resulting in the description of several new Fragilaria taxa and the reseparation of some forms formerly regarded as synonyms (Tuji 2007; TuJi \& Williams 2006a, 2006b, 2008a, 2008b, 2013; Linares-Cuesta \& SÁnchezCAstillo 2007; Wetzel \& Ector 2015; Delgado et al. 2015, 2016; KAHLERT et al. 2019; NovAIs et al. 2019; VAN DE ViJVER \& ECTOR 2020; VAN DE ViJVER et al. 2020a, 2020b, 2020c), there are still a large number of populations that cannot be identified with certainty. In most cases, these populations are composed of relatively long (30-70 $\mu \mathrm{m}$ ), elongated, slender (max. valve width $4 \mu \mathrm{m}$ ) Fragilaria taxa with a relatively high number of striae (15-20 in $10 \mu \mathrm{m})$ that could often be confused with F. capucina s.s. As in cleaned material typical ribbonshaped colonies, are not always easy to find, incorrect identifications often occur. Several of these unidentified populations were recently discovered in diatom gatherings from rivers in Sweden and the United Kingdom. Since they are often abundant in these rivers, it is not always easy to correctly assess ecological condition of these rivers. A careful analysis of these populations, together with a good determination of their ecological preferences, becomes, therefore, very important. The question of whether these populations represent new species can only be answered after obtaining a better knowledge of the taxonomic history of some of these taxa. Earlier analyses showed that some of these populations were already described in the nineteenth century as varieties of $F$. capucina. As mentioned earlier, Albert
Grunow (1826-1914) described and illustrated several of these taxa in the Atlas of the Synopsis des Diatomées de Belgique (VAN Heurck 1881), based on material collected by Charles-Henri Delogne (1834-1901), a contemporary Belgian diatomist with whom Van Heurck often collaborated. Material of these samples is kept in the Van Heurck collection, housed in the herbarium of Meise Botanic Garden (Belgium).

The present paper analyses these original gatherings of $F$. capucina Desmazières, $F$. capucina var. acuta Grunow and $F$. capucina var. acuminata Grunow together with type material of the recently described $F$. nevadensis Linares-Cuesta et Sánchez-Castillo and F. sandellii Van de Vijver et Jarlman. In addition, a population of the latter, identified as Synedra parvula Kützing, was examined from a slide in H.L. Smith's Diatomacearum Species Typicae (no. 572, SмITH 1876-1888), also kept in Meise Botanic Garden. Comparison of the Fragilaria populations from Sweden and the UK revealed that three taxa could not be identified and should therefore be described as new: Fragilaria malouana Van de Vijver et Jarlman nov. sp., F. battarbeeana Van de Vijver, M.Kelly, C.E.Wetzel et Ector nov. sp. and F. ennerdalensis Van de Vijver, M.Kelly, C.E.Wetzel et Ector nov. sp. All species are illustrated using both LM and SEM observations and compared with the morphology of other Fragilaria species worldwide.

\section{Material ANd Methods}

Table 1 lists all samples used in this study including the type material of several species: Fragilaria capucina Desmazières, F. nevadensis Linares-Cuesta et Sánchez-Castillo, F. sandellii Van de Vijver et Jarlman, F. capucina var. acuta Grunow and F. capucina var. acuminata Grunow.

Sub-samples of the selected material were prepared for light and scanning electron microscopy observations following the method described in VAN DER WERFF (1955). Small parts of the samples were cleaned by adding $37 \% \mathrm{H}_{2} \mathrm{O}_{2}$ and heating to $80{ }^{\circ} \mathrm{C}$ for about $1 \mathrm{~h}$. The reaction was completed by addition of saturated $\mathrm{KMnO}_{4}$. Following digestion and centrifugation (three times 10 minutes at $3700 \times \mathrm{rpm}$ ), the resulting cleaned material was diluted with distilled water to avoid excessive concentrations of diatom valves on the slides. Cleaned material was mounted in Naphrax. The resulting slides were analysed using an Olympus BX53 microscope, equipped with Differential Interference Contrast (Nomarski) optics and the Olympus UC30 Imaging System. For each taxon, the number of specimens measured at random on the type slide is indicated $(n=X)$. For scanning electron microscopy (SEM), parts of the oxidized suspensions were filtered through a $5-\mu \mathrm{m}$ Isopore ${ }^{\mathrm{TM}}$ polycarbonate membrane filter (Merck Millipore). Filters were mounted on aluminium stubs and coated with platinum using a BAL-TEC MED 020 Modular High Vacuum Coating System for $30 \mathrm{~s}$ at $100 \mathrm{~mA}$. An ultra-high-resolution analytical field emission (FE) scanning electron microscope Hitachi SU-70 (Hitachi High-Technologies, Europe, $\mathrm{GmbH}$ ) operated at 5 $\mathrm{kV}$ and $10 \mathrm{~mm}$ working distance was used for the analysis.

Terminology used in the description of the structures of the siliceous cell wall follows Ross et al. (1979), WiLLIAMS 


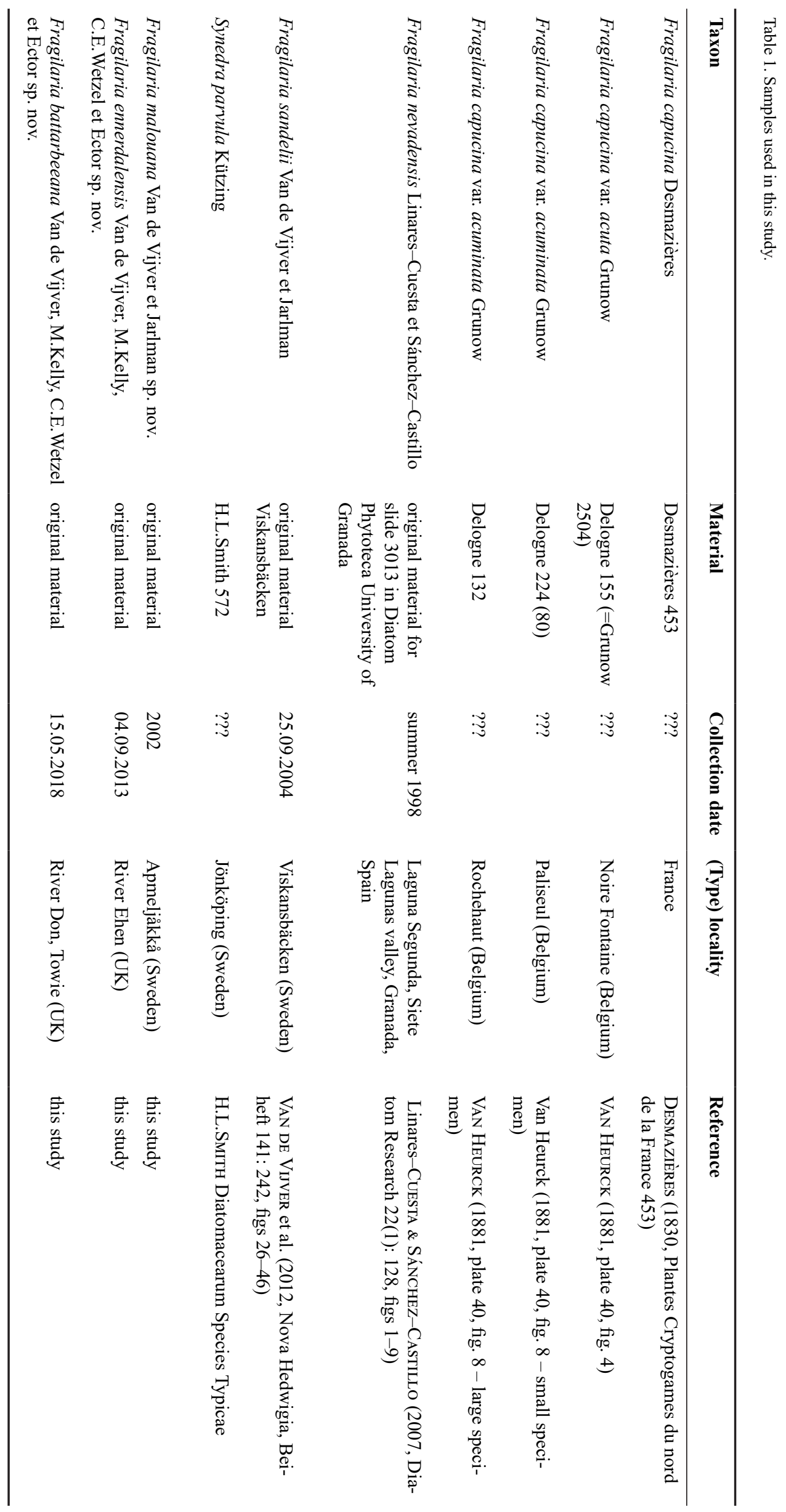


\& Round (1987) and Round et al. (1990). For taxonomic comparisons, the following papers were used: KRAMMER \& Lange-Bertalot (1991), Tuji \& Williams (2006a), LinaresCuesta \& SÁnchez-Castillo (2007), VAn de Vijver et al. (2012), Delgado et al. (2015), LANGE-Bertalot et al. (2017) and Novais et al. (2019).

\section{RESULTS}

In this section, we first present morphological descriptions of each of the investigated populations and species under the name they were given. It is clear that some of these require a new, appropriate, name. Synonymy between some these populations will be discussed later. For each species, analysis of the accompanying diatom flora has been added in an attempt to better delineate the habitat preferences of each of the populations, based on the dominating diatom flora. Table 2 provides an overview of the morphological observations of all discussed species.

\section{Fragilaria capucina Desmazières 1830 (Figs 1-23) Description}

LM (Figs 1-15): Frustules in girdle view rectangular, linked to each to other to form very long, ribbon-shaped colonies often composed of more than 25 cells (Figs $1,2)$. Valves linear, never narrowly lanceolate, with almost parallel margins, narrowing abruptly short before apices. Apices cuneately protracted, longer valves weakly rostrate, shorter valves never protracted. Valve dimensions $(n=20)$ : length 24-70 $\mu \mathrm{m}$, width 3.5-4 $\mu \mathrm{m}$. Sternum narrow, up to $1 / 5$ of total valve width, linear, gradually widening towards central area. Central area usually forming a large hyaline zone lacking striae, occasionally slightly swollen (Figs 3, 8). Ghost striae only rarely observed (Fig. 8), usually absent. Striae parallel to weakly radiate throughout entire valve, $15-16$ in $10 \mu \mathrm{m}$. SEM (Figs 16-23): Striae uniseriate, composed of small, rounded areolae (Figs 16, 17), continuing onto valve mantle (Fig. 18). Areolae externally occluded by individual hymenes (Fig. 18). Ghost striae visible in the central area (Figs 16, 23). Continuous series of marginal linking spines running from apex to apex (Fig. 16). Spines spathulate (Figs 18, 23). Several narrower spines present at apices (Figs 17, 19, 22). Most marginal spines corresponding with vimines (Figs 16-19). Large mantle plaques visible at mantle edge (Fig. 18). Two rimoportulae present per valve (Fig. 20, arrows), located on each apex, usually at the end of the last stria (Figs 16, 17, 19 arrows). Rimoportulae oblique, formed by two raised labia (Figs 21, 22, arrows). Small apical pore field
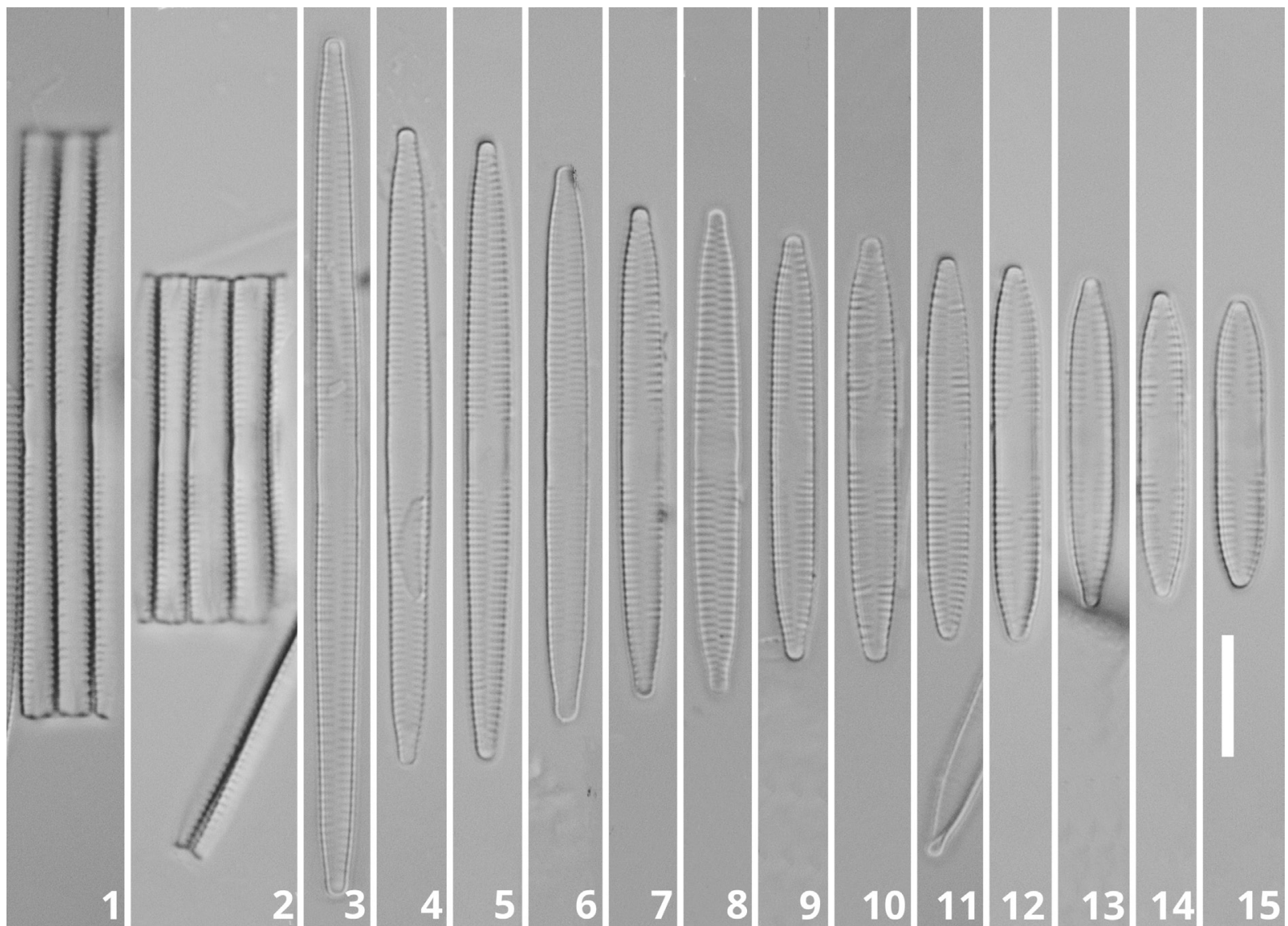

Figs 1-15. Fragilaria capucina Desmazières, LM images taken from the type material (France sample 453$)$ : $(1,2)$ two views of several frustules in girdle view, connected to form a ribbon-shaped colony; (3-15) LM views of the population arranged in decreasing length. Scale bar represents $10 \mu \mathrm{m}$. 
on mantle, composed of up to 6 parallel rows of small pores (Figs 19, 22). Internally, virgae well developed, joining sternum at centre, appearing raised from sunken vimines (Fig. 22).

Analysed material: Desm., Pl. Crypt. N. France, Fasc. 10, no. 453 (type material).

Lectotype: designated by TuJi \& Williams (2006a, Taxon, p. 98, fig 6O): an individual from BM 81302 in BM (located at England finder Q33-1).

Associated diatom flora: The type sample of F. capucina is dominated by a wide range of diatom taxa such as Melosira varians C.Agardh, Gomphonema parvulum Kützing, Planothidium frequentissimum (Lange-Bertalot) Lange-Bertalot, P. lanceolatum (Brébisson ex Kützing) Lange-Bertalot and Navicula cryptotenella LangeBertalot. Less frequent taxa include Nitzschia amphibia
Grunow, N. supralitorea Lange-Bertalot, Surirella terricola Lange-Bertalot et Alles, Achnanthidium jackii Rabenhorst, A. microcephalum Kützing and Encyonema silesiacum (Bleisch) D.G.Mann.

Fragilaria capucina var. acuta Grunow in Van Heurck 1881 (Figs 24-56)

\section{Description}

LM (Figs 25-51): Frustules in girdle view rectangular, linked to each to other forming very long, ribbon-shaped colonies, often composed of more than 50 cells (Figs 25, 26). Valves strictly lanceolate, with clearly convex, occasionally undulating, margins, gradually tapering towards the apices. Apices protracted, mostly rostrate, short valves only weakly protracted. Valve dimensions $(\mathrm{n}=40)$ : length $12-35 \mu \mathrm{m}$, width 3-4 $\mu \mathrm{m}$. Sternum narrow to very narrow, maximum $1 / 5-1 / 10$ of total valve
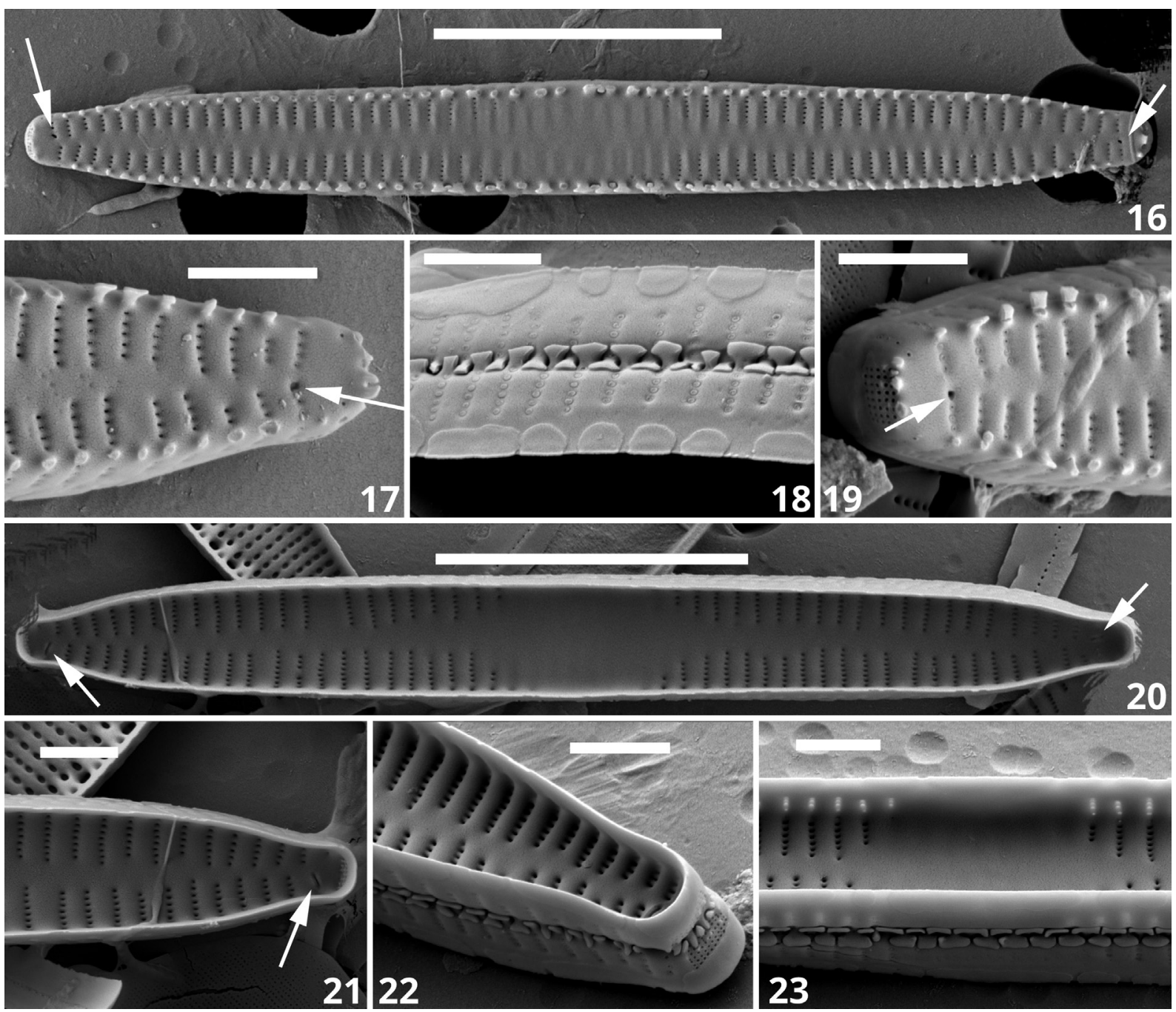

Figs 16-23. Fragilaria capucina Desmazières, SEM images taken from the type material (France sample 453): (16) SEM external view of an entire valve. The arrows indicate the two rimoportulae. (17) Detail of one apex with the linking spines and the rimoportula (arrow). (18) SEM external detail of two valves linked together. Note the linking spines and the large mantle plaques. (19) SEM external detail of the valve apex showing the rimoportula and the apical pore field. (20) SEM internal view of an entire valve showing the two rimoportulae (arrows) at the apices. (21) SEM internal detail showing the eccentric position of the rimoportula (arrow). (22) SEM internal view of one valve connected to another with linking spines. The apical pore field is well visible. (23) SEM internal view of the central area. Scale bars represent $10 \mu \mathrm{m}$ (16, $20)$ and $2 \mu \mathrm{m}(17-19,21-23)$. 
width, linear, gradually widening towards central area. Central area variable: absent, asymmetrical or forming moderately large hyaline zone. Marginal striae always present in central area, ghost striae often visible. Striae parallel near central area becoming weakly radiate towards apices, 15-19 in $10 \mu \mathrm{m}$.

SEM (52-56): Girdle composed of several open girdle bands (Fig. 52). Large mantle plaques visible at mantle edge (Fig. 52). Frustules connected to each other by linking spines (Figs 52, 53). Spines spatulate (Fig. 52), present as continuous series on valve face/margin junction, always located at end of a stria in line with vimines (Figs 54, 55). Close to, and at the valve apices, spines acute (Fig. 53). Striae uniseriate, composed of small, rounded to weakly transapically elongated areolae (Figs $54,55)$, continuing onto valve mantle (Figs 52, 53). Areolae occlusions not observed in SEM, possibly due to sample preparation. Ghost striae clearly visible in the central area, as solid area in place of vimines (Fig. 54, arrows). One rimoportulae present per valve, located at apex, more or less isolated between last two striae (Fig. 54, arrow). Small, well-defined apical pore field visible at apices, composed of up to four parallel rows of small pores (Fig. 53). Internally, virgae slightly raised separating sunken striae (Fig. 56). Rimoportula oblique, formed by two raised labia (Fig. 56, arrow).

Analysed material: Noire Fontaine (Luxembourg province, Belgium), sample Delogne 155 (type material).

Lectotype (here designated): BR-4637 (Meise Botanic Garden, Belgium) prepared from material Delogne 155.

Associated diatom flora: The lectotype sample of $F$. capucina var. acuta is almost entirely dominated by this Fragilaria taxon. Only a handful of other taxa could be observed in the sample of which Planothidium lanceolatum, Frustulia vulgaris (Thwaites) De Toni, Eunotia exigua (Brébisson) Rabenhorst and Psammothidium helveticum (Hustedt) Bukhtiyarova et Round are the most important.

\section{Fragilaria capucina var. acuminata Grunow in Van Heurck 1881 (Figs 57-102) \\ Description}

LM (Figs 57-95): Frustules in girdle view rectangular, linked to each to other to form very long, ribbon-shaped colonies often composed of more than 40 cells (Figs 57, $84,85)$. Valves lanceolate, with clearly convex margins gradually tapering towards apices. Longer valves with typically undulating margins having their greatest width at the central area. Apices protracted, rostrate,

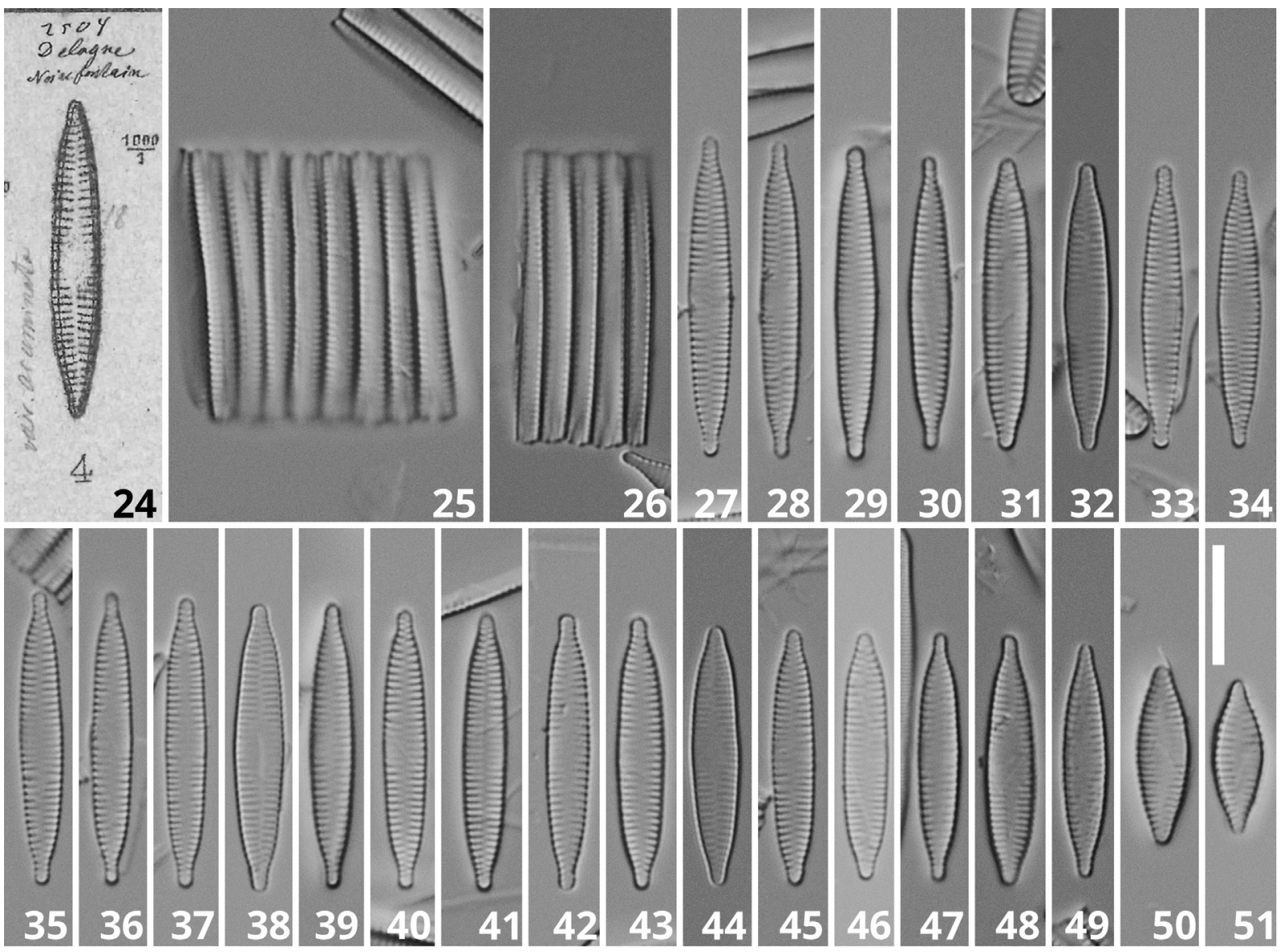

Figs 24-51. Fragilaria capucina var. acuta Grunow, LM images taken from the type material (Noire Fontaine, Delogne 155): (24) original drawing in VAN HEURCK (1881, plate 45, fig. 4); $(25,26)$ two views of several frustules in girdle view, connected to form a ribbon-shaped colony; (27-51) LM views of the population arranged in decreasing length. Scale bar represents $10 \mu \mathrm{m}$. 
short valves only weakly protracted. Valve dimensions $(\mathrm{n}=50)$ : length 14-60 $\mu \mathrm{m}$, width 4-5 $\mu \mathrm{m}$. Sternum usually narrow, maximum $1 / 8$ of total valve width, linear, gradually widening only near central area. Central area irregularly shaped, occasionally absent, asymmetrical, forming large hyaline zone spanning entire valve width. Marginal striae in central area always present, ghost striae often visible. Striae parallel near central area, gradually becoming weakly radiate towards apices, 17-19 in $10 \mu \mathrm{m}$. SEM (96-102): Girdle composed of several, perforated, open girdle bands (Fig. 96). Large mantle plaques visible at the mantle edge (Figs 96, 97). Frustules connected to each other by linking spines (Figs 96, 97). Spines broadly spatulate (Fig. 97) with truncated tops. Spines marginal, visible as continuous series on valve face/margin junction (Fig. 97), always located at end of a stria (Fig. 99). Spines typically acute close to and at the valve apices (Fig. 100). Striae uniseriate, composed of small, rounded areolae (Figs 98, 99), continuing onto valve mantle (Fig. 100). Areolae occluded externally by individual hymenes (Fig. 99). Central area with ribbed pattern of ghost striae (Fig. 102). One rimoportula present per valve, located at apex (Fig. 99, arrow). Small, well-defined apical pore field visible at apices, composed of up to four parallel rows of small pores (Fig. 99). Internally, virgae raised separating sunken striae (Figs 101, 102). Rimoportula
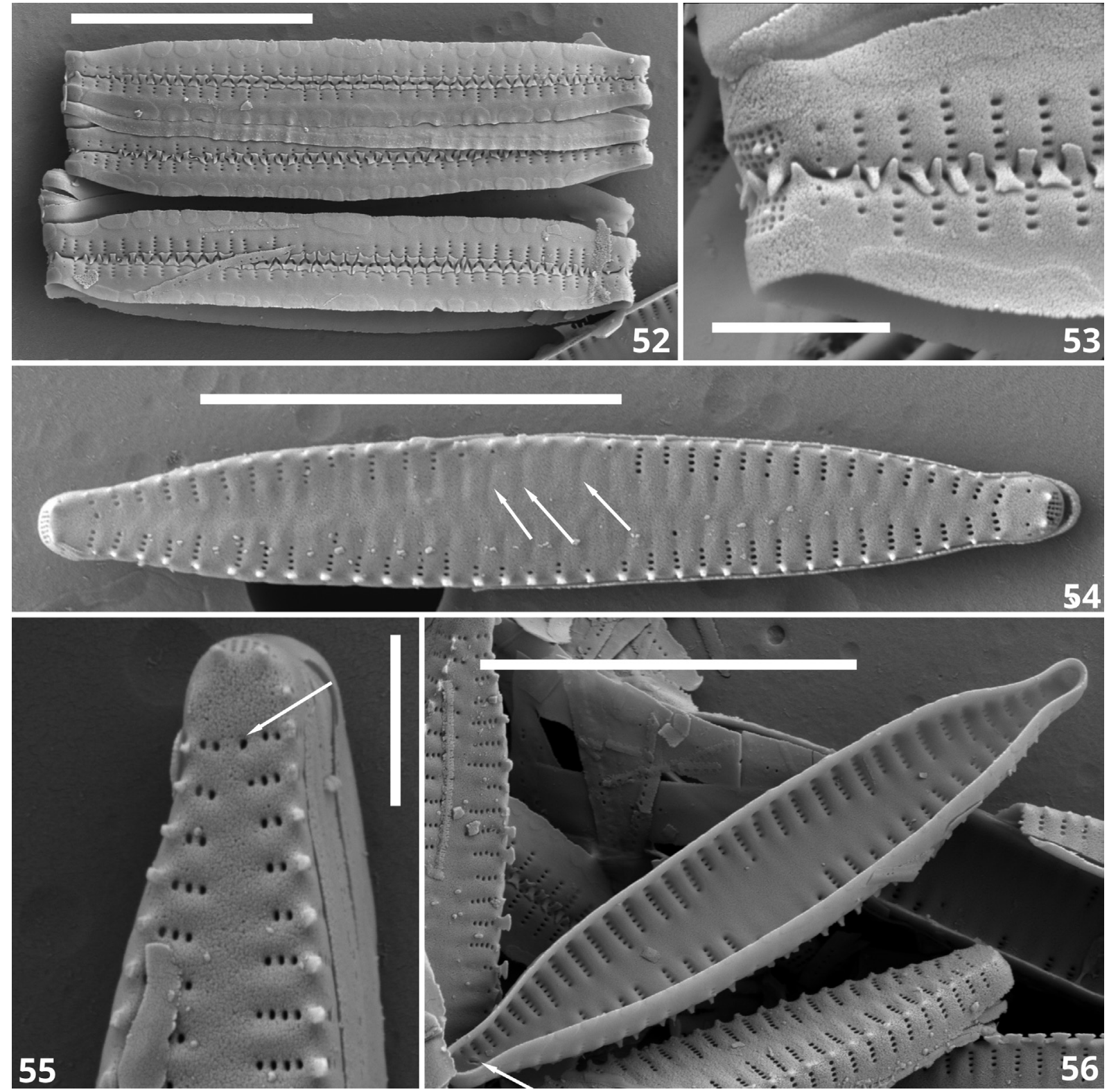

Figs 52-56. Fragilaria capucina var. acuta Grunow, SEM images taken from the type material (Noire Fontaine, Delogne 155): (52) several frustules in girdle view connected to each other via linking spines. The structure of the girdle with open copulae is well visible. (53) external detail of the apices of two valves in girdle view. Note the linking spines and the acute spines at the apices above the apical pore fields. (54) external view of an entire valve. The arrows indicate several ghost striae. (55) detail of one apex with the linking spines and the rimoportula (arrow). (56) SEM internal view of an entire valve showing the rimoportula (arrow) at the apex. Scale bars represent $10 \mu \mathrm{m}(52,54,56)$ and $2 \mu \mathrm{m}(53,55)$. 
Table 2. Comparison table of all Fragilaria taxa discussed in this paper.

\begin{tabular}{lllll}
\hline & Fragilaria capucina & $\begin{array}{l}\text { Fragilaria capucina } \\
\text { var. } \text { acuta }\end{array}$ & $\begin{array}{l}\text { Fragilaria capucina } \\
\text { var. acuminata }\end{array}$ & Fragilaria nevadensis \\
\hline Reference & DESMAZIÈres (1830) & $\begin{array}{l}\text { GRUNOW in VAN HEU- } \\
\text { RCK }(1881)\end{array}$ & $\begin{array}{l}\text { GRUNOW in VAN HEU- } \\
\text { RCK }(1881)\end{array}$ & $\begin{array}{l}\text { LINARES-CUESTA \& SÁN- } \\
\text { CHEZ-CASTILLO (2007) }\end{array}$ \\
Figures & $1-23$ & $24-56$ & $57-102$ & $103-124$ \\
Colonies & ribbon-shaped & ribbon-shaped & ribbon-shaped & ribbon-shaped \\
Length $(\mu \mathrm{m})$ & $24-70$ & $12-35$ & $14-60$ & $20-50$ \\
Width $(\mu \mathrm{m})$ & $3.5-4$ & $3-4$ & $4-5$ & ca. 4 \\
Valve outline & $\begin{array}{l}\text { linear, never narrowly } \\
\text { lanceolate, with almost } \\
\text { parallel margins }\end{array}$ & $\begin{array}{l}\text { strictly lanceolate, with } \\
\text { clearly convex, oc- } \\
\text { casionally undulating } \\
\text { margins }\end{array}$ & $\begin{array}{l}\text { lanceolate, with clearly } \\
\text { convex margins }\end{array}$ & $\begin{array}{l}\text { lanceolate, with clearly } \\
\text { convex, always undulat- } \\
\text { ing margins }\end{array}$ \\
& & & &
\end{tabular}

$\begin{array}{lllll}\text { Apices } & \begin{array}{l}\text { cuneately protracted, } \\ \text { longer specimens weak- } \\ \text { ly rostrate, short valves } \\ \text { never protracted }\end{array} & \begin{array}{l}\text { protracted, mostly ros- } \\ \text { trate, short valves only } \\ \text { weakly protracted }\end{array} & \begin{array}{l}\text { protracted, rostrate, } \\ \text { short valves only weakly } \\ \text { protracted }\end{array} & \text { protracted, rostrate } \\ \text { Central area } & \begin{array}{l}\text { usually forming a large } \\ \text { hyaline zone lacking } \\ \text { striae, occasionally } \\ \text { slightly swollen }\end{array} & \begin{array}{l}\text { variable, absent, asym- } \\ \text { metrical to forming a } \\ \text { moderately large hya- } \\ \text { line zone }\end{array} & \begin{array}{l}\text { irregularly shaped, } \\ \text { occasionally absent, } \\ \text { asymmetrical to form- } \\ \text { ing a large hyaline zone } \\ \text { spanning the entire valve }\end{array} & \begin{array}{l}\text { a large hyaline zone } \\ \text { spanning the entire } \\ \text { vidth }\end{array} \\ \text { valdth }\end{array}$

oblique, formed by two raised labia (Figs 101, 102).

Analysed material: Paliseul (Luxembourg province, Belgium), sample Delogne 224 (Figs 57-83), Rochehaut (Luxembourg province, Belgium), sample Delogne 132 (Figs 84-95) (type material).

Lectotype (here designated): BR-4638 (Meise Botanic Garden, Belgium) prepared from Delogne 132.

Remarks: Fragilaria capucina var. acuminata Grunow in Van Heurck 1881 (pl. 45, fig. 8, with two figures) was based on material from Paliseul (a Delogne sample) according to Van Heurck (1885, p. 156). The annotated copy of Van Heurck (1881) makes it clear that of the two valves illustrated for Fragilaria capucina var. acuminata, the smaller one (left) was drawn from a Paliseul sample, the larger from the Rochehaut sample (Fig. 83). Grunow, however, most likely used a different sample from Paliseul (Delogne 80 instead of Delogne 224). For the sample Delogne 80, only a slide with hand-written label, was retrieved from the Van Heurck collection. The tube with unmounted material for sample 80 was empty. For Delogne 224, on the other hand, sufficient unmounted material was available and contained an identical diatom flora to Delogne 80. This material is, therefore, used in subsequent analyses to represent the Paliseul sample. The number of the Delogne samples 
Table 2 Cont.

\begin{tabular}{|c|c|c|c|c|}
\hline Fragilaria sandellii & $\begin{array}{l}\text { Synedra parvula sensu } \\
\text { H.L.Smith }\end{array}$ & Fragilaria malouana & $\begin{array}{l}\text { Fragilaria } \\
\text { battarbeeana }\end{array}$ & $\begin{array}{l}\text { Fragilaria } \\
\text { ennerdalensis }\end{array}$ \\
\hline $\begin{array}{l}\text { VAN DE ViJVER et al. } \\
\text { (2012) }\end{array}$ & this study & this study & this study & this study \\
\hline $125-143$ & $144-173$ & $174-199$ & $200-223$ & $224-247$ \\
\hline none & none & none & none & none \\
\hline $11-24$ & $11-70$ & $25-60$ & $12-38$ & $22-48$ \\
\hline $4.5-6$ & $4.5-6$ & $3-4$ & $3.5-5$ & $3-4$ \\
\hline $\begin{array}{l}\text { elliptic-lanceolate } \\
\text { to lanceolate in } \\
\text { longer valves with } \\
\text { distinctly convex } \\
\text { margins }\end{array}$ & $\begin{array}{l}\text { linear-lanceolate be- } \\
\text { coming lanceolate and } \\
\text { even elliptic-lanceolate } \\
\text { in the smallest valves } \\
\text { with straight (larger } \\
\text { valves) to convex } \\
\text { (smaller valves) mar- } \\
\text { gins }\end{array}$ & $\begin{array}{l}\text { linear to very narrow- } \\
\text { ly linear-lanceolate, } \\
\text { with almost parallel } \\
\text { to weakly convex } \\
\text { margins }\end{array}$ & $\begin{array}{l}\text { lanceolate, with } \\
\text { weakly to, in smaller } \\
\text { margins }\end{array}$ & $\begin{array}{l}\text { linear to very narrowly } \\
\text { linear-lanceolate, with } \\
\text { almost parallel to, in } \\
\text { smaller valves, weakly } \\
\text { convex margins }\end{array}$ \\
\hline $\begin{array}{l}\text { slightly protracted, } \\
\text { subrostrate to acute- } \\
\text { ly rounded }\end{array}$ & $\begin{array}{l}\text { broadly rounded, } \\
\text { protracted and often } \\
\text { rostrate }\end{array}$ & $\begin{array}{l}\text { slightly protracted, } \\
\text { rostrate to acutely } \\
\text { rounded apices }\end{array}$ & protracted, rostrate & protracted, subrostrate \\
\hline $\begin{array}{l}\text { large unilateral } \\
\text { hyaline zone with } \\
\text { weakly shortened } \\
\text { striae on the other } \\
\text { side }\end{array}$ & $\begin{array}{l}\text { asymmetrical, forming } \\
\text { a large hyaline spot on } \\
\text { one side with slightly } \\
\text { shortened striae on the } \\
\text { other side, often asym- } \\
\text { metrically swollen }\end{array}$ & $\begin{array}{l}\text { clearly asymmetrical } \\
\text { forming a distinct } \\
\text { unilaterally hyaline } \\
\text { zone with on the other } \\
\text { side almost no short- } \\
\text { ened striae }\end{array}$ & $\begin{array}{l}\text { clearly asymmetrical, } \\
\text { unilaterally expanded, } \\
\text { forming a distinct } \\
\text { hyaline zone on one } \\
\text { side with almost not } \\
\text { shortened striae on the } \\
\text { other }\end{array}$ & $\begin{array}{l}\text { asymmetrical, slightly } \\
\text { swollen and unilater- } \\
\text { ally expanded, forming } \\
\text { a distinct unilateral } \\
\text { hyaline zone with on the } \\
\text { other side irregularly } \\
\text { shortened striae }\end{array}$ \\
\hline occasionally visible & not observed & only rarely observed & only rarely observed & occasionally observed \\
\hline $18-19$ & $18-20$ & $17-19$ & $18-19$ & $17-18$ \\
\hline 1 & no SEM possible & 1 & 1 & 1 \\
\hline $\begin{array}{l}\text { small, narrow, } \\
\text { acute, located on the } \\
\text { striae }\end{array}$ & no SEM possible & $\begin{array}{l}\text { small, thick, acute, } \\
\text { located on the striae }\end{array}$ & $\begin{array}{l}\text { thick, conical, located } \\
\text { on the virgae }\end{array}$ & $\begin{array}{l}\text { small, shark tooth- } \\
\text { shaped, located on the } \\
\text { striae }\end{array}$ \\
\hline
\end{tabular}

proved, however, not to be always correct making it highly likely that Delogne 80 and Delogne 224 are, in fact, one and the same sample.

The following description is therefore based on the combination of the morphological observations of the two populations from Rochehaut and Paliseul.

Associated diatom flora: The lectotype sample of $F$. capucina var. acuminata (Rochehaut, Delogne 132) is dominated, apart from this Fragilaria taxon, by Meridion constrictum Ralfs, Odontidium mesodon (Ehrenberg) Kützing, Fragilariforma virescens (Ralfs) D.M.Williams et Round, Fragilaria cf. gracilis Østrup as most abundant taxa. Other taxa in the slide include Achnanthidium minutissimum (Kützing) Czarnecki, Frustulia vulgaris and Ulnaria ulna (Nitzsch) Compère. The Paliseul samples (Delogne 80 \& 224) have a similar flora except that several other taxa such as Cymbopleura naviculiformis (Auerswald) Krammer, Tabellaria flocculosa (Roth) Kützing, Frustulia erifuga Lange-Bertalot et Krammer, Eunotia bilunaris (Ehrenberg) Schaarschmidt and Gomphonema exilissimum (Grunow) Lange-Bertalot et E.Reichardt are also abundant. 

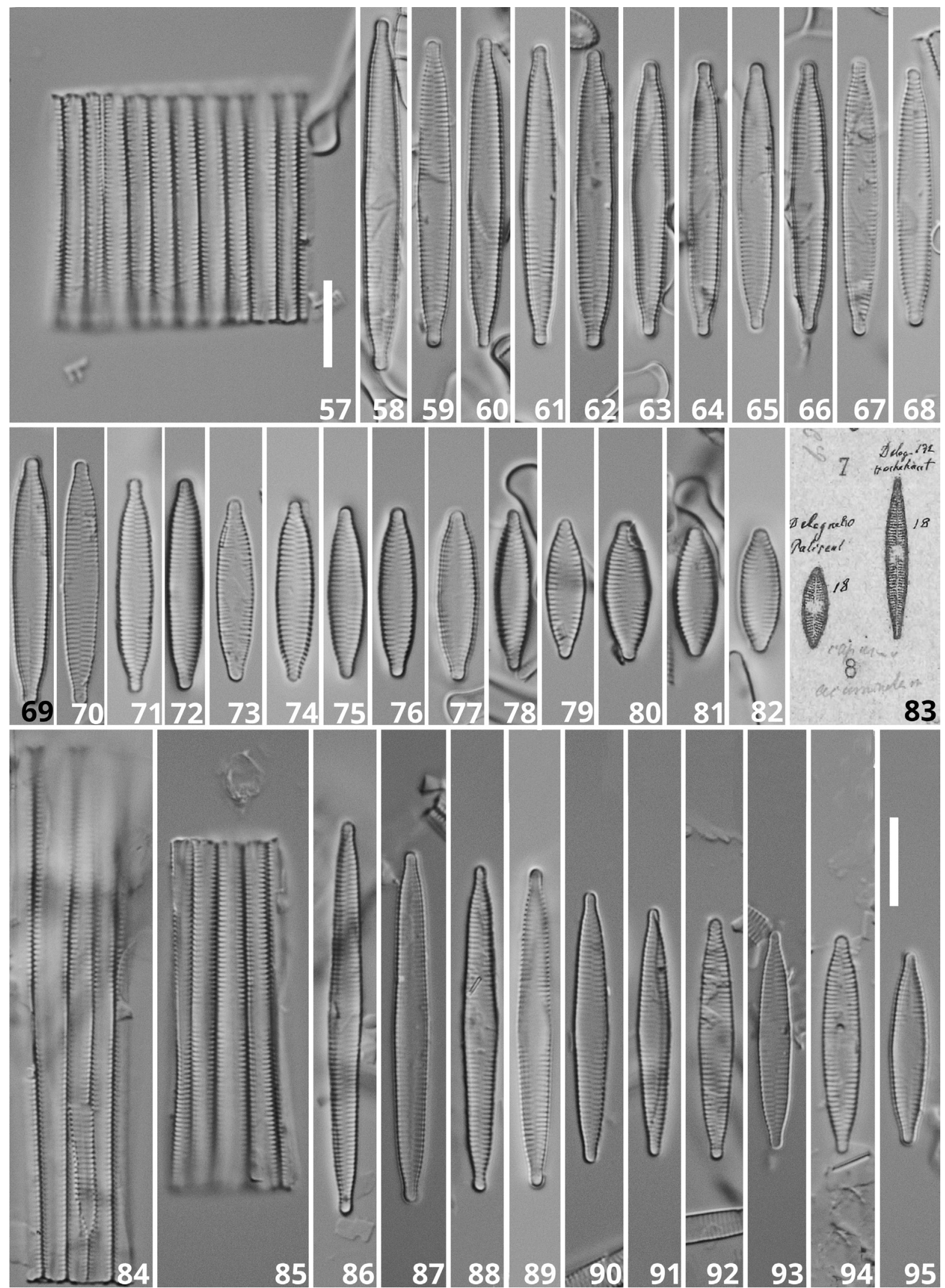

Figs 57-95. Fragilaria capucina var acuminata Grunow, LM images taken from the type material (57-83: Paliseul, Delogne 224, 84-95: Rochehaut, Delogne 132): (57) one view of several frustules in girdle view, connected to form a ribbon-shaped colony; (58-82) LM views of the population arranged in decreasing length; (83) original drawing in VAN HEURCK (1881, plate 45, fig. 8); (84, 85) two views of several frustules in girdle view, connected to form a ribbon-shaped colony; (86-95) LM views of the population arranged in decreasing length. Scale bar represents $10 \mu \mathrm{m}$. 

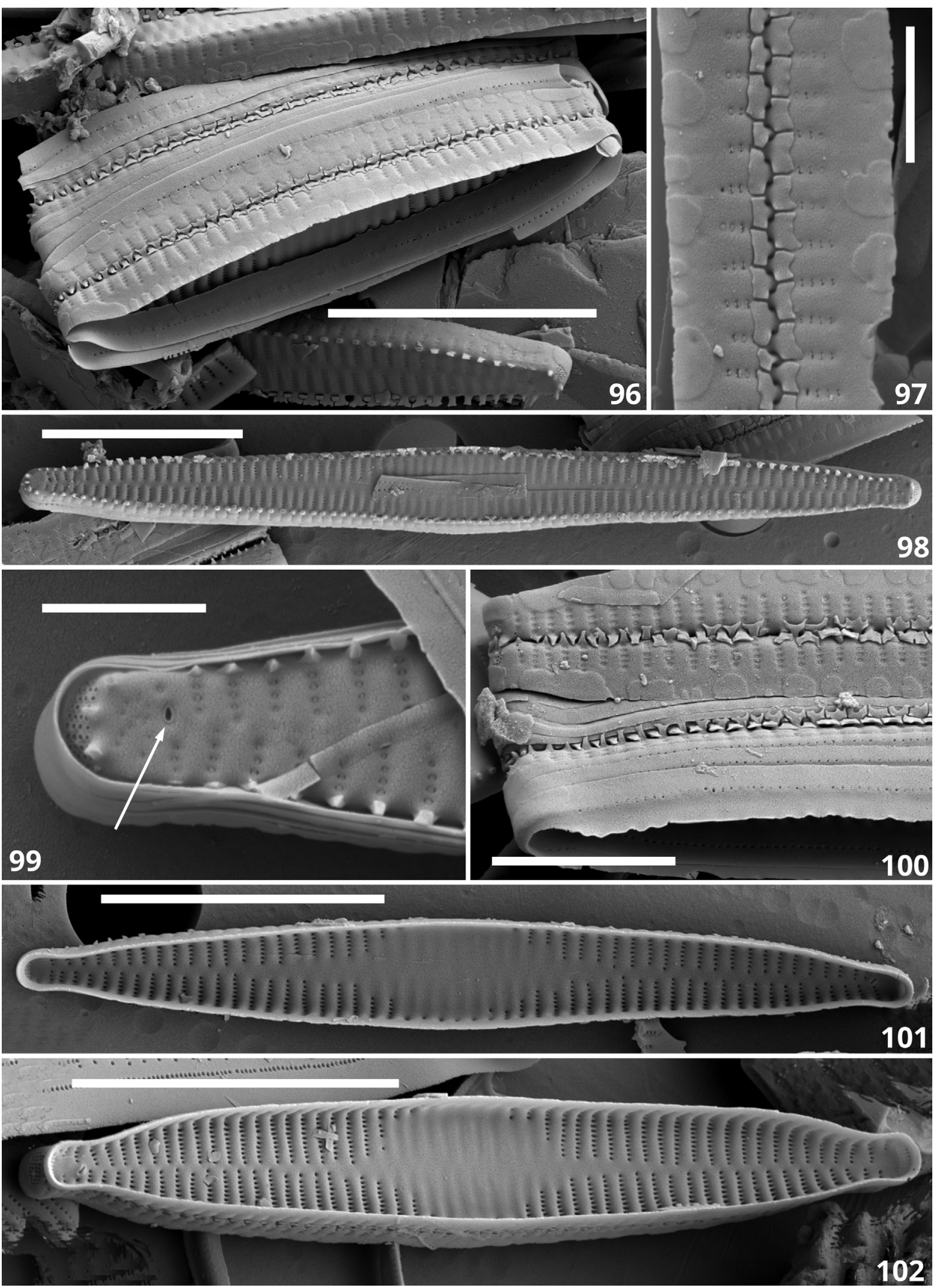

Figs 96-102. Fragilaria capucina var. acuminata Grunow, SEM images taken from the type material (96-101: Paliseul, Delogne 224, 102: Rochehaut, Delogne 132): (96) several frustules in girdle view connected to each other via linking spines. The structure of the girdle with open copulae is well visible. (97) SEM external detail of two valves linked together. Note the linking spines and the large mantle plaques. (98) external view of an entire valve. (99) detail of one apex with the rimoportula. (100) external detail of valve apices in girdle view showing the linking spines. (101) SEM internal view of an entire valve showing the rimoportula at the apex. (102) SEM internal view of an entire valve showing the rimoportula at the apex. Scale bars represent $10 \mu \mathrm{m}(96,98,101,102)$ and $2 \mu \mathrm{m}(97,99,100)$. 


\section{Fragilaria nevadensis Linares-Cuesta et Sánchez- Castillo (2007, p. 128, figs 1-9)}

non Fragilaria nevadensis Lohman 1957, invalid

\section{Description}

LM (Figs 103-120): Frustules in girdle view rectangular, linked to each to other, forming short ribbon-shaped colonies (Fig. 103). Long, ribbon-shaped colonies not observed in LM, only individual linked valves. Valves lanceolate, with clearly convex, always undulating, margins gradually tapering towards apices. Smallest valves with non-undulating margins. Apices protracted, rostrate throughout entire valve diminution series. Valve dimensions ( $\mathrm{n}=15)$ : length 20-50 $\mu \mathrm{m}$, width ca. $4 \mu \mathrm{m}$. Sternum very narrow, maximum $1 / 8$ of total valve width, linear, gradually widening only near central area. Central area forming a large hyaline zone spanning entire valve width. Ghost striae often visible. Striae parallel near central area gradually becoming weakly radiate towards apices, 17-18 in $10 \mu \mathrm{m}$.

SEM (121-124): Frustules connected to each other
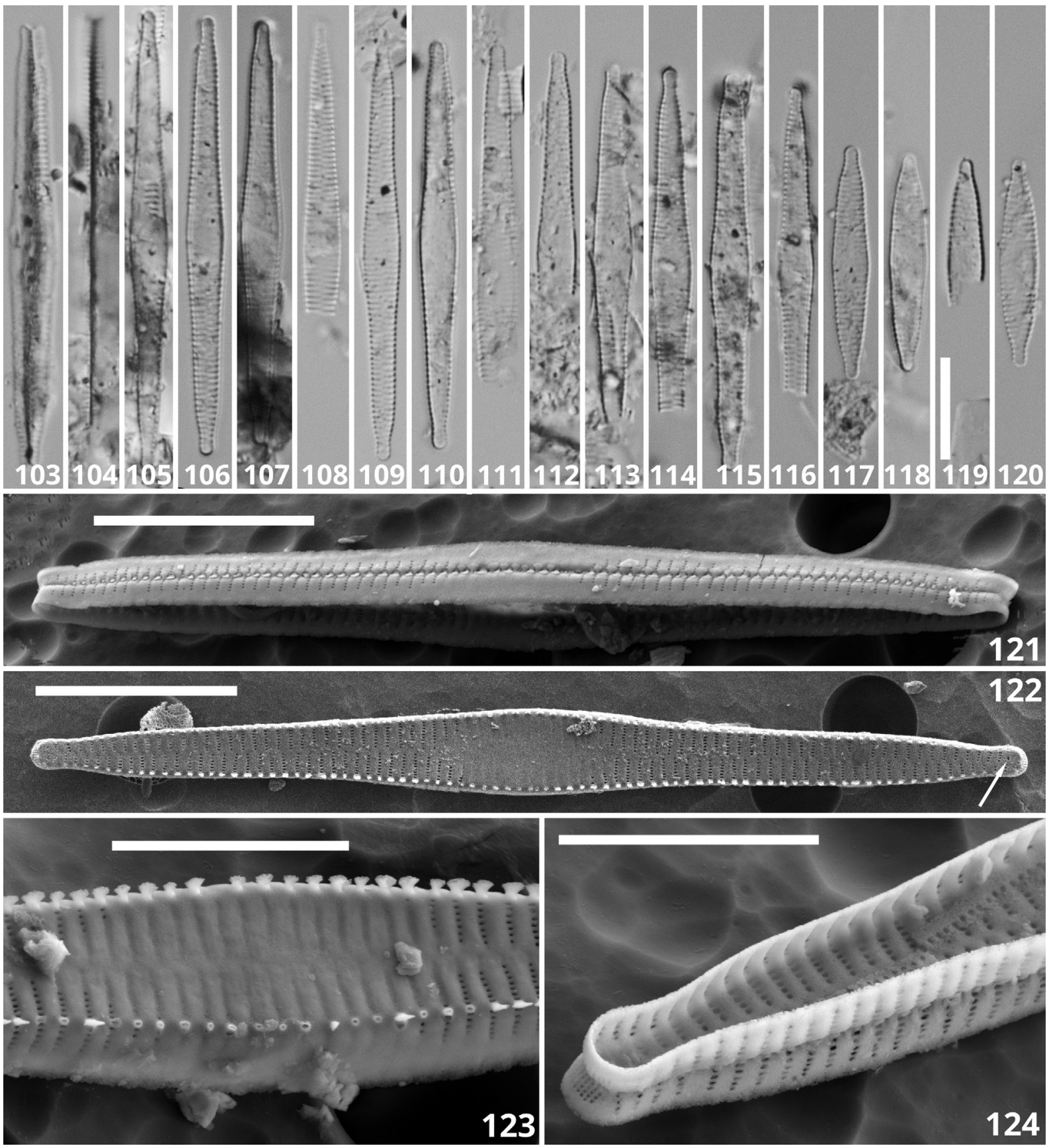

Figs 103-124. Fragilaria nevadensis Linares-Cuesta et Sánchez-Castillo, all images taken from the type material (Laguna Segunda, Siete lagunas Valley, Granada, Spain): $(103,104)$ two views of valves in girdle view, connected to each other; $(105-120)$ LM views of the type population arranged in decreasing length; (121) SEM external view of two valves connected to each other via linking spines; (122) external view of an entire valve. The arrow indicates the rimoportula. (123) SEM external detail of the central area showing the ghost striae and the linking spines; (124) SEM internal view of the valve apex showing the rimoportula at the apex. Scale bars represent $10 \mu \mathrm{m}(103-122)$ and $5 \mu \mathrm{m}(123,124)$. 
by spatulate linking spines (Fig. 121), broken spines appearing hollow (Fig. 123) located as continuous series on valve face/margin junction (Fig. 122), always located at end of a stria (Fig. 123). Striae uniseriate, composed of small, rounded to weakly transapically elongated areolae (Fig. 122), continuing onto the valve mantle (Figs 121, 124). Central area with ribbed pattern of ghost striae (Fig. 123), extending onto mantle (Figs $121,123)$. One rimoportulae present per valve, located at apex, replacing one of the last striae (Fig. 122, arrow). Small, well-defined apical pore field visible at apices, composed of up to four parallel rows of small pores (Fig. 124). Internally, virgae raised separating sunken striae (Fig. 124). Rimoportula oblique, formed by two raised labia (Fig. 124).

Analysed material: Laguna Segunda, Siete lagunas Valley, Granada, Spain.

Associated diatom flora: The type material of the Fragilaria nevadensis is dominated by Staurosira venter Ehrenberg, Fragilariforma virescens, Odontidium mesodon, Meridion constrictum and Nitzschia hantzschiana Rabenhorst.

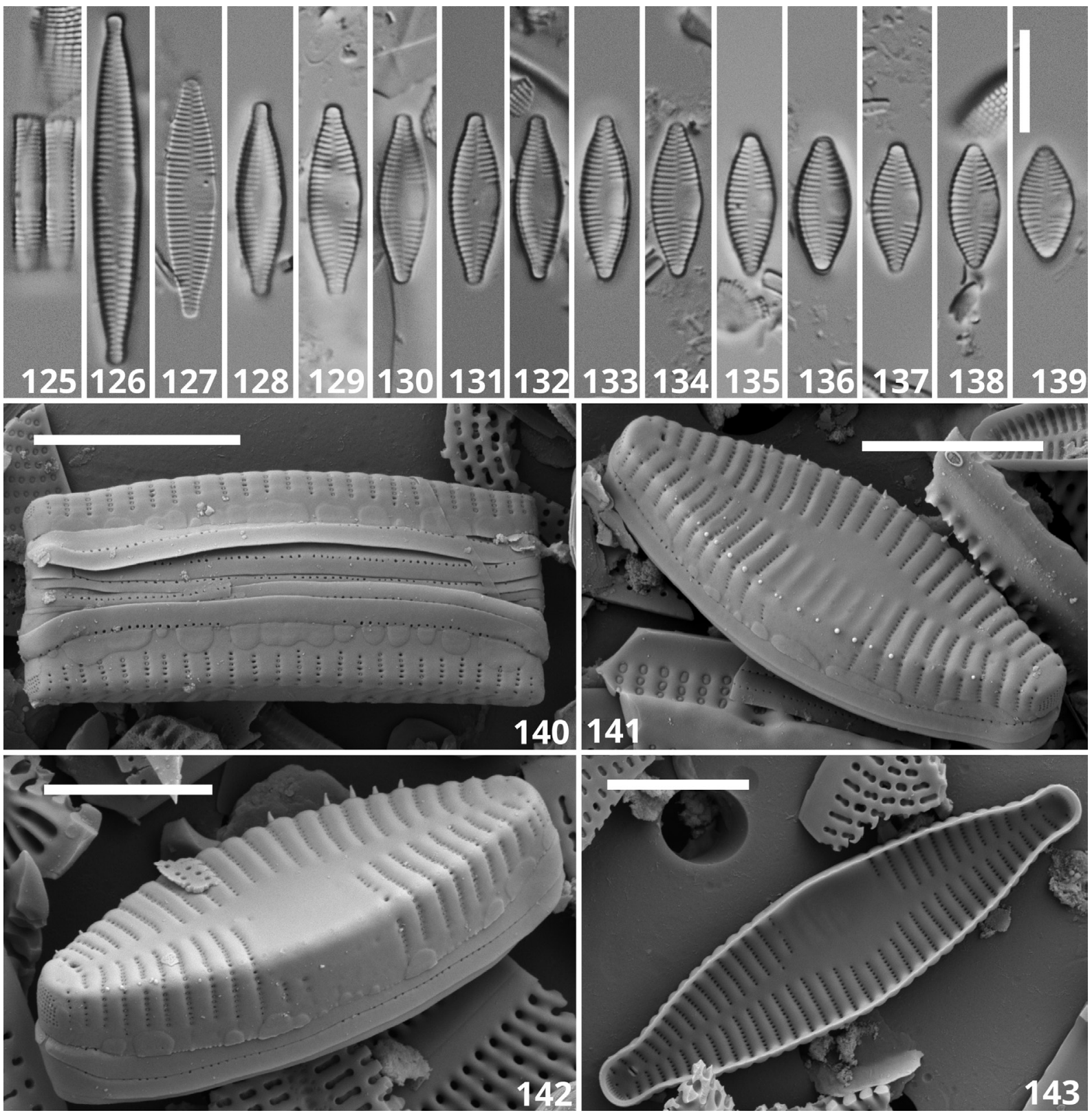

Figs 125-143. Fragilaria sandellii Van de Vijver et Jarlman, all images taken from the type material (Viskansbäcken, Sweden): (125) two frustules in girdle view, connected to each other; (126-139) LM views of the type population arranged in decreasing length; (140) SEM external view of two frustules showing mantle plaques and the open girdle bands; (141) external view of an entire valve in oblique view. Note the very tiny spines. (142) external view of an entire valve in oblique view. Note the very tiny spines and the rimoportula. (143) SEM internal view of the entire valve showing the rimoportula at the apex. Scale bars represent $10 \mu \mathrm{m}$. 


\section{Fragilaria sandellii Van de Vijver et Jarlman in Van de Vijver et al. 2012 (Figs 125-143) \\ Description}

LM (Figs 125-139): Frustules rectangular, solitary or maximum two cells together (Fig. 125). Valves elliptic-lanceolate to lanceolate in longer valves. Margins distinctly convex. Apices slightly protracted, subrostrate to acutely rounded. Valve dimensions $(\mathrm{n}=15)$ : length 11-24 (35) $\mu \mathrm{m}$, width 4.5-6.0 $\mu \mathrm{m}$. Sternum very narrow, maximum $1 / 10$ of the total valve width, linear, gradually widening towards central area. Central area forming large unilateral hyaline zone with weakly shortened, and striae on opposite side converging towards sternum. Ghost striae occasionally, and faintly, visible. Striae weakly radiate throughout valve, $18-19$ in $10 \mu \mathrm{m}$.
SEM (140-143): Girdle composed of several, open, perforated copulae (Fig. 140, open portion of valvocopula illustrated in Fig. 142). Mantle plaques clearly visible at mantle edge (Fig. 140-142). Short, marginal, very thin, acute spines present at valve face/mantle junction, running from apex to apex (Figs 141, 142). Striae weakly curved, uniseriate, composed of small, rounded areolae (Fig. 141), continuing onto valve mantle (Figs 121, 124), externally occluded by individual hymenes (Fig. 142). Central area asymmetrical, with occasionally a ribbed pattern of ghost striae on one side (Figs 141, 142). One rimoportulae present per valve, located at apex in one of the last striae (Figs 141, 142, arrows). Apical pore field relatively large, well-defined, composed of 5-8 parallel rows of small pores (Figs 141, 142). Internally, virgae

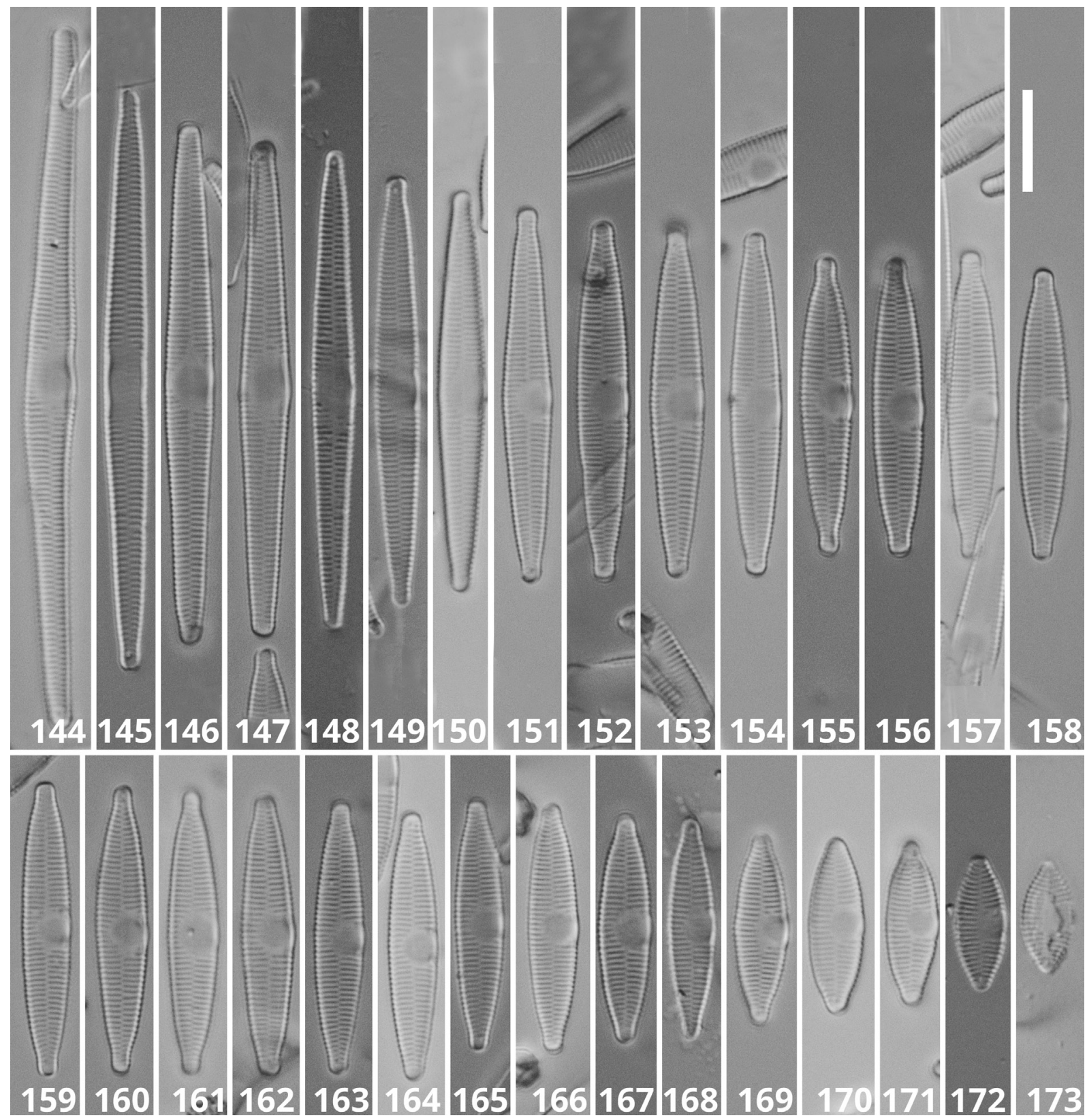

Figs 144-173. Synedra parvula Kützing, LM images taken from the H.L. Smith slide 572 (Jönköping, Sweden), LM views of the population arranged in decreasing length: (144) most likely represents an initial valve. Scale bar represents $10 \mu \mathrm{m}$. 
raised separating sunken striae (Fig. 143). Rimoportula almost straight, formed by two raised labia (Fig. 143). Analysed sample: "Viskansbäcken, central Sweden", 25.IX.2004 (VAN DE VIJVER et al. 2012: 242) (BR slide BR-4204, holotype $=$ VAN DE VIJVER et al. 2012: fig. 29).

Associated diatom flora: The type material of the Fragilaria sandellii is dominated by Cocconeis placentula Ehrenberg s.1., Fragilaria cf. rumpens, Gomphonema parvulum, Fragilaria vaucheriae and F. pararumpens Lange-Bertalot et al., Achnanthidium microcephalum with $F$. sandellii only playing a very minor role in this sample. Less frequent taxa include Reimeria sinuata (W.Gregory) Kociolek et Stoermer, Hannaea arcus (Ehrenberg) R.M.Patrick and Achnanthidium catenatum (J.Bílý et Marvan) Lange-Bertalot.

\section{Synedra parvula Kützing sensu H.L.Smith (Figs 144-173) \\ Description}

LM (Figs 144-173): Larger valves linear-lanceolate becoming lanceolate and even elliptic-lanceolate in smallest valves. Margins straight to convex in smaller valves. Apices broadly rounded, protracted and often rostrate. Valve dimensions $(n=30)$ : length $11-70 \mu \mathrm{m}$, width 4.5-6.0 $\mu \mathrm{m}$. Sternum very narrow, only very weakly widening near central area. Central area asymmetrical, forming a large hyaline space to one side, slightly shortened striae on other side. Central area often asymmetrically swollen, having a buttressed appearance. Striae slightly radiate throughout entire valve, $18-20$ in $10 \mu \mathrm{m}$.

Analysed sample: H.L. Smith Diatomacearum Species
Typicae, slide no. 572 (century 6, 1880), Jonkoping (= Jönköping), Sweden.

Associated diatom flora: Slide 572 is entirely dominated by Synedra parvula sensu H.L.Smith. Only a few other species were found in the sample, always in very low numbers: Gomphonema ventricosum W.Gregory, Ulnaria cf. ulna and Encyonema silesiacum.

Fragilaria malouana Van de Vijver et Jarlman nov. sp. (Figs 174-199)

\section{Description}

LM (Figs 174-192): Frustules rectangular in girdle view, solitary or two cells together (Fig. 174). Ribbon-shaped colonies never observed. Valves linear to very narrowly linear-lanceolate, with almost parallel to weakly convex margins, gradually tapering towards slightly protracted, rostrate to acutely rounded apices. Valve dimensions $(n=25)$ : length 25-60 $\mu \mathrm{m}$, width 3-4 $\mu \mathrm{m}$. Sternum very narrow, up to $1 / 8$ of total valve width, linear, only at central area weakly widening. Central area clearly asymmetrical forming a distinct unilaterally hyaline zone, opposite side almost no shortened striae; occasionally, very narrow (Fig. 181). Ghosts striae only rarely observed (Figs 182, 187), usually absent. Striae parallel to weakly radiate throughout valve, $17-19$ in $10 \mu \mathrm{m}$.

SEM (Figs 193-199): Striae uniseriate, composed of small, rounded areolae (Figs 193-196), continuing onto valve mantle (Fig. 197). Areolae occlusions not observed, probably due to severe sample preparation. Continuous series of small, acute spines running from apex to apex, never present at the apices; spines situated

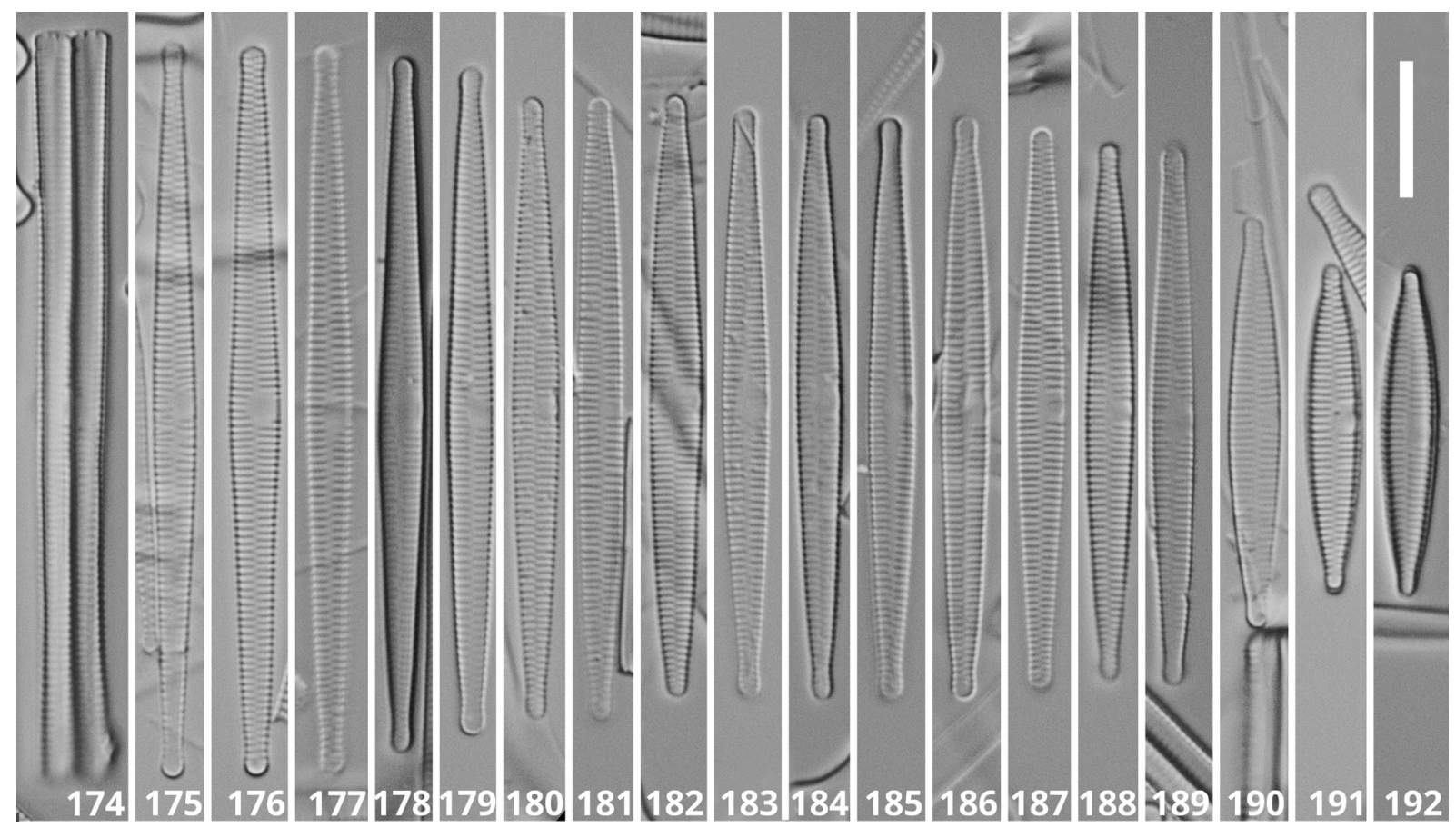

Figs 174-192. Fragilaria malouana Van de Vijver et Jarlman sp. nov., LM images taken from the type population (Apmeljåkkå, Sweden): (174) two frustules in girdle view, connected to each other; (175-192) LM views of the population arranged in decreasing length. Scale bar represents $10 \mu \mathrm{m}$. 
on virgae (Figs 193-197). Large mantle plaques visible at mantle edge (Fig. 197). Small, irregular depressions present on mantle (Fig. 197). One rimoportula present per valve, replacing last stria at one apex (Figs 193, 194, arrows). Large apical pore field visible at apices, composed of up to 7 parallel rows of small pores (Figs 194, 195). Internally, virgae weakly raised separating sunken striae (Fig. 196). One rimoportula visible, clearly oblique, formed by two raised labia (Fig. 197).

Holotype: BR-4639 (Meise Botanic Garden, Belgium). Isotype: PLP-384 (University of Antwerp, Belgium). Type locality: Apmeljåkkå, Sweden, (leg. Mikael
Östlund, 2002).

Etymology: species is named after Malou Jarlman Chrigström, first granddaughter of Amelie Jarlman, author of the species and this paper.

Associated diatom flora: The type sample of $F$. $m a$ louana is dominated by several araphid diatoms. The most dominant species are A. minutissimum, Fragilaria perdelicatissima Lange-Bertalot et Van de Vijver, F. tenera (W.Smith) Lange-Bertalot, Tabellaria cf. flocculosa and Hannaea linearis (Holmboe) Álvarez-Blanco et S.Blanco. Other important (raphid) species include Brachysira
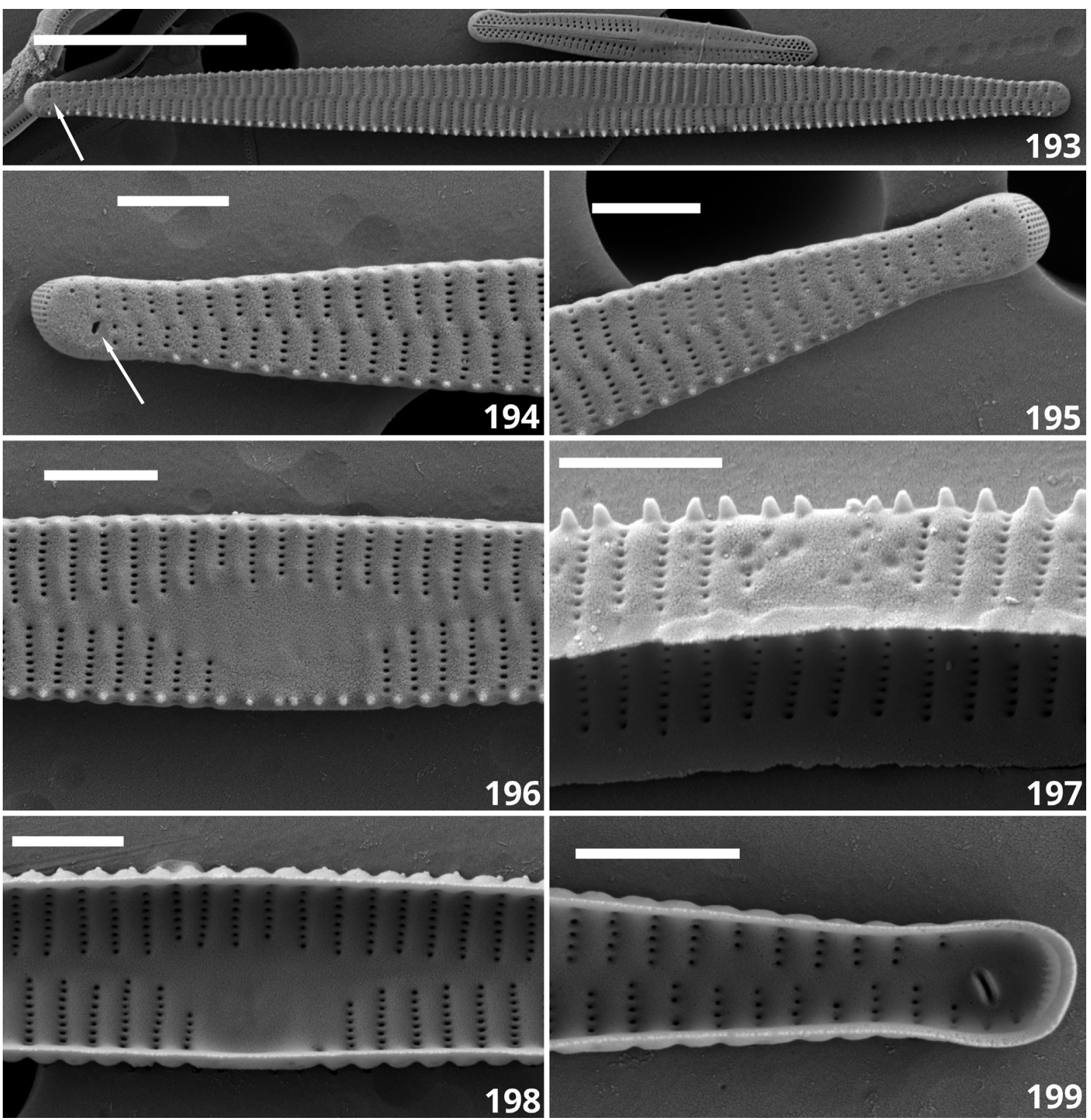

Figures 193-199. Fragilaria malouana Van de Vijver et Jarlman sp. nov., SEM images taken from the type population (Apmeljåkkå, Sweden): (193) SEM external view of an entire valve. The arrow indicates the rimoportula. (194) detail of one apex with the small spines and the rimoportula (arrow); (195) detail of the other apex of the same valve lacking a rimoportula but showing its apical pore field; (196) SEM external detail of the central area showing the hyaline zone and the small spines; (197) SEM external view of the valve mantle showing the plaques, the small conical spines and the irregular depressions; (198) SEM internal detail showing the central area; (199) SEM internal view of the apex with the rimoportula. Scale bars represent $10 \mu \mathrm{m}$ (193) and $2 \mu \mathrm{m}$ (194-199). 
neoexilis Lange-Bertalot, various Cymbella species and Achnanthidium lineare W.Smith. The sample was characterized by an alkaline $\mathrm{pH}(8.0)$, a low conductivity value of $88 \mu \mathrm{S} . \mathrm{cm}^{-1}$, low nutrient $\left(\mathrm{NH}_{4}-\mathrm{N} 5 \mu \mathrm{g} . \mathrm{l}^{-1}\right.$, $\left.\mathrm{NO}_{2+3}-\mathrm{N} 25 \mu \mathrm{g} .1^{-1}\right)$ and phosphate $\left(\mathrm{PO}_{4}-\mathrm{P} 1 \mu \mathrm{g} .1^{-1}\right)$ levels.

\section{Fragilaria battarbeeana Van de Vijver, M.Kelly, C.E.Wetzel et Ector sp. nov. (Figs 200-223) Description}

LM (Figs 200-216): Frustules solitary. Ribbon-shaped colonies never observed. Valves lanceolate, with weakly to clearly convex margins, the latter in smaller valves, gradually tapering towards protracted, rostrate, subcapitate to even capitate apices. Valve dimensions $(n=25)$ : length 12-38 $\mu \mathrm{m}$, width 3.5-5.0 $\mu \mathrm{m}$. Sternum very narrow, up to $1 / 8$ of total valve width, linear, occasionally weakly widening only at central area. Central area clearly asymmetrical, unilaterally expanded, forming distinct hyaline zone on one side with barely shortened striae on the other. Ghost striae only rarely observed (Fig. 210), usually absent. Striae parallel to very weakly radiate, only becoming more radiate near apices, 18-19 in $10 \mu \mathrm{m}$.

SEM (Figs 217-223): Striae uniseriate, slightly sunken between raised virgae (Fig. 218), composed of small, rounded areolae (Figs 217-219, 221), continuing onto valve mantle (Fig. 217). Areolae occlusions not observed, probably due to severe sample preparation. Continuous series of thick, conical spines running from apex to apex but never present at the apices (Figs 217-219, 221); present on virgae, occasionally two spines per virga (Figs 218, 219). Broken and eroded spines leaving a shallow depression (Fig. 218). One rimoportula present per valve, replacing one of last striae at one apex (Figs 217, 219, arrows). Large apical pore field visible at apices, composed of up to 7 parallel rows of small pores (Figs 219, 221). Internally, virgae not raised (Figs 220, 222, 223). One large rimoportula visible, weakly oblique, formed by two raised labia (Fig. 223).

Holotype: BR-4640 (Meise Botanic Garden, Belgium). Isotype: PLP-385 (University of Antwerp, Belgium). Type locality: UK, River Don, Towie, Aberdeenshire (leg. Sarah Stenhouse, 15/5/2018).

Etymology: The species was named after Professor Richard (Rick) William Battarbee, an eminent British palaeoecologist and Fellow of the Royal Society (FRS), to honor him for his important work on diatom ecology and palaeoecology.

Associated diatom flora: The type sample of $F$. battarbeeana has a very diverse diatom flora composed of a large number of species. The most important ones are long valves identified as Hannaea arcus, Gomphonema olivaceoides Hustedt, Ulnaria cf. ulna, several Fragilaria taxa such as F. cf. gracilis and F. cf. vaucheriae, Achnanthidium gracillimum (F.Meister) Lange-Bertalot, A. pyrenaicum (Hustedt) H.Kobayasi, Encyonema silesiacum and Odontidium mesodon. Average water chemistry between November 1999 and
December 2016 was as follows: $\mathrm{pH}: 7.7$, conductivity: $124 \mu \mathrm{S} . \mathrm{cm}^{-1}$ and very high levels of nitrate-N (3.34 $\left.\mathrm{mg} . \mathrm{l}^{-1}\right)$. The latter high values may be skewed by one or two extreme values; the average concentration of TN, by contrast, is $0.57 \mathrm{mg} \cdot \mathrm{l}^{-1}$.

Fragilaria ennerdalensis Van de Vijver, M.Kelly, C.E.Wetzel et Ector sp. nov. (Figs 224-247) Description

LM (Figs 224-243): Frustules solitary. Ribbon-shaped colonies never observed. Valves linear to very narrowly linear-lanceolate, with almost parallel to weakly convex margins, the latter in smaller valves, gradually tapering towards protracted, subrostrate apices. Valve dimensions $(\mathrm{n}=25)$ : length $22-48 \mu \mathrm{m}$, width 3-4 $\mu \mathrm{m}$. Sternum very narrow, up to $1 / 8$ of total valve width, linear, usually not widening towards central area. Central area clearly asymmetrical, slightly swollen and unilaterally expanded, forming a distinct unilateral hyaline zone with irregularly shortened striae on opposite side. Ghost striae occasionally observed (Figs 230, 231). Striae parallel becoming weakly radiate near apices, $17-18$ in $10 \mu \mathrm{m}$.

SEM (Figs 244-247): Striae usually uniseriate, composed of small, rounded areolae (Fig. 244), although occasionally, biseriate striae present (Fig. 245). Areolae occlusions not observed, probably due to severe sample preparation. Ghost striae clearly visible in central area as long, arrow slits (Fig. 245). Continuous series of small, shark tooth-shaped spines running from apex to apex, never present at the apices (Figs 244, 245). One rimoportula present per valve, replacing the last stria at one apex (Figs 244, 246, arrows). Apical pore fields present at both apices. Internally, virgae only very weakly raised (Fig. 247). One rimoportula visible, clearly oblique, formed by two raised labia (Fig. 247, arrow).

Holotype: BR-4641 (Meise Botanic Garden, Belgium). Isotype: PLP-386 (University of Antwerp, Belgium). Type locality: UK, River Ehen, Ennerdale, Cumbria (leg. Martyn Kelly, 15/5/2018).

Etymology: The species was named after Ennerdale, a valley in the English Lake District, UK, through which the River Ehen flows.

Associated algal flora: The type sample of F. ennerdalensis also has a very diverse diatom flora composed of a large number of, mostly araphid, species. Several other Fragilaria taxa are prominently present in the sample including $F$. tenera, $F$. cf. pararumpens, $F$. cf. vaucheriae, F. cf. gracilis together with Hannaea arcus and Tabellaria flocculosa. Abundant raphid taxa include Gomphonema cf. parvulum and Achnanthidium microcephalum.

This part of the River Ehen has very soft water, with alkalinity often below the detection limit $\left(5 \mathrm{mg} \cdot 1^{-1}\right.$ $\mathrm{CaCO}_{3}$ ). Median $\mathrm{pH}$ for a nearby site was 7.1 whilst conductivity was $45 \mu \mathrm{S} . \mathrm{cm}^{-1}$ and total $\mathrm{Ca}$ was 2.1 $\mathrm{mg} . \mathrm{l}^{-1}$. Median reactive phosphorus and nitrate- $\mathrm{N}$ are both below detection limit $\left(0.001 \mathrm{mg} .1^{-1}\right.$ and $0.5 \mathrm{mg} . \mathrm{l}^{-1}$ 

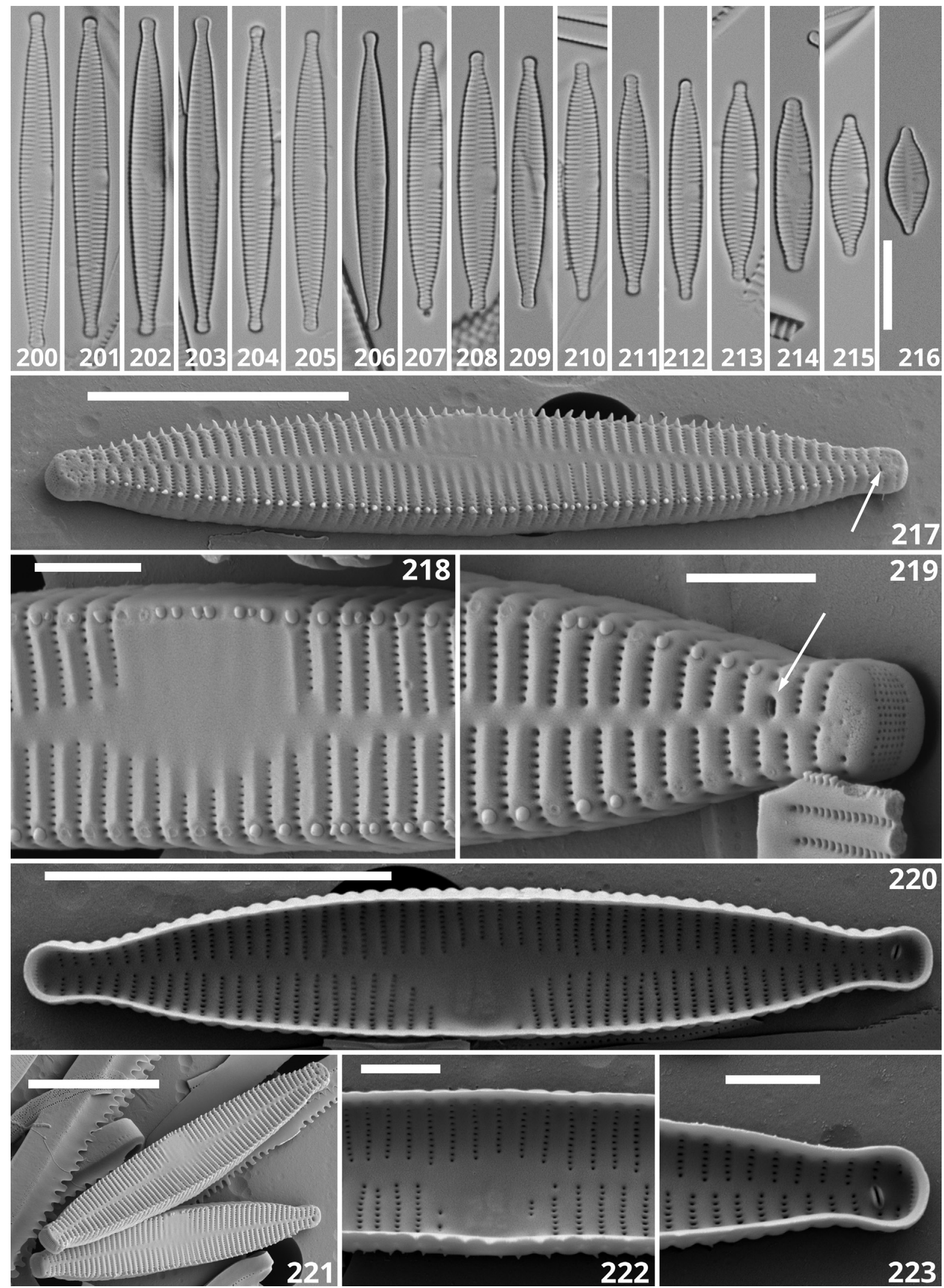

Figs 200-223. Fragilaria battarbeeana Van de Vijver, M.Kelly, C.E.Wetzel et Ector sp. nov., all images taken from the type population (River Don, Towie, Aberdeenshire, UK): (200-216) LM views of the population arranged in decreasing length; (217) SEM external view of an entire valve; (218) SEM external detail of the central area showing the hyaline zone and the small, conical spines, located on the virgae; (219) detail of one apex with the small spines and the rimoportula; (220) SEM internal view of an entire valve; (221) SEM external view of two entire valves; (222) SEM internal detail showing of the central area; (223) SEM internal view of the apex with the rimoportula. Scale bars represent $10 \mu \mathrm{m}$ $(220-217,220,221)$ and $2 \mu \mathrm{m}(218,219,222,223)$ 
respectively) as are other pollution variables such as BOD and ammonia-N. The main pressure on this part of the river is low flow due to the impoundment of Ennerdale for use as a water supply reservoir. The stretch of the river below the lake has a diverse assemblage of other algae, with often rich growths of green algae (Spirogyra sp., Mougeotia sp., Draparnaldia glomerata (Vaucher) C.Agardh, Bulbochaete sp., Nitella flexilis) as well as Cyanobacteria (Tolypothrix tenuis Kützing ex Bornet et
Flahault, Phormidium autumnale Gomont) and Rhodophyta (Audouinella hermannii (Roth) Duby and Lemanea fluviatilis (Linnaeus) C.Agardh). This section of the river is designated as a Special Area of Conservation, with a relatively healthy population of freshwater pearl mussels (Margaritifera margaritifera (Linnaeus)).
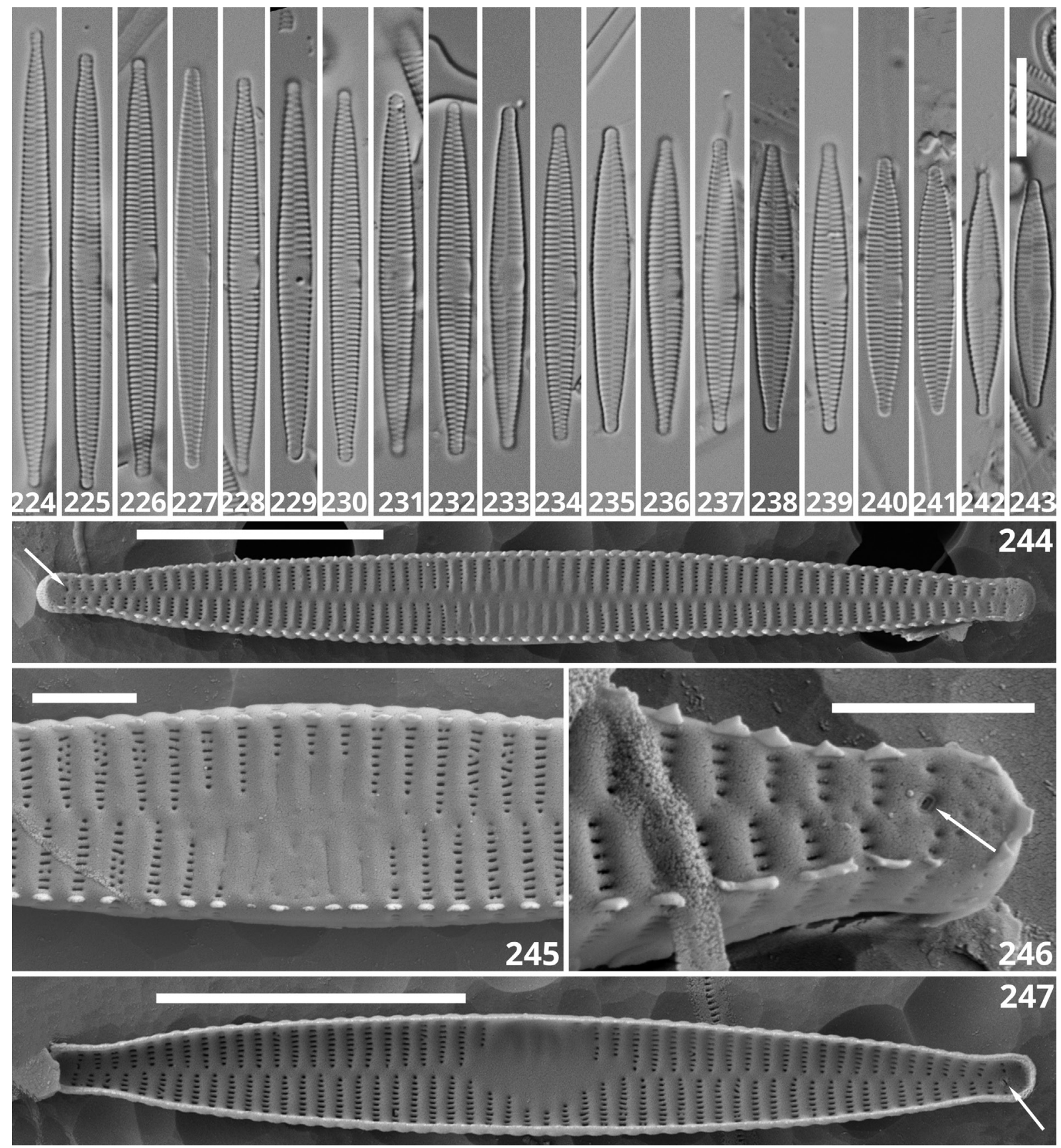

Figs 224-247. Fragilaria ennerdalensis Van de Vijver, M.Kelly, C.E.Wetzel et Ector sp. nov., all images taken from the type population (River Ehen, Ennerdale, Lake District, UK): (224-243) LM views of the population arranged in decreasing length; (244) SEM external view of an entire valve. The arrow indicates the rimoportula. (245) SEM external detail of the central area showing the hyaline zone and the small, flattened spines, located on the striae. Several striae with doubling of the areolae. (246) detail of one apex with the flattened, shark-tooth shaped spines and the rimoportula (arrow). (247) SEM internal view of an entire valve with the rimoportula indicated by an arrow. Scale bars represent $10 \mu \mathrm{m}(224-244,247)$ and $2 \mu \mathrm{m}(245,246)$. 


\section{DisCUSSION}

The results of this study have several taxonomic implications. Fragilaria nevadensis was originally described from the Spanish Sierra Nevada and since has only occasionally been recorded, with records mainly concentrated in southern Europe (Portugal, Spain, southern France: Linares-Cuesta \& SÁnChez-Castillo 2007; Bey \& ECtor 2013; Tierno de Figueroa et al. 2013; RIVERA-RONDÓN \& CATALAN 2017), although several populations were also reported from eastern France (PeEters \& ECtor 2017) and Luxembourg (Coles et al. 2016). However, it is now clear that the species has been observed in more European localities, but usually under a different name. Comparison of the morphology for $F$. nevadensis, $F$. capucina var. acuta and $F$. capucina var. acuminata supports the view that these are all conspecific with no marked differences. The type population of Fragilaria capucina var. acuta consists entirely of shorter valves than $F$. capucina var. acuminata and $F$. nevadensis, but comparison of the smaller valves of the latter two taxa with the var. acuta population revealed no morphological differences. Valve width, striae density, shape and position of the spines, structure of the central area and general valve outline are similar in all three taxa. Following Article 11.2 of the International Code of Nomenclature for algae, fungi, and plants (Shenzhen Code) (TurLand et al. 2018), the names of varieties have no priority over the names of species ("A name has no priority outside the rank at which it is published"). Therefore, F. capucina var. acuta and var. acuminata should be considered synonyms of $F$. nevadensis, despite the fact that the latter was described more than 100 years after the two varieties.

Grunow's use of the name Fragilaria capucina var. acuta is problematic. In the plate legend in VAN HEURCK (1881, pl. 45, fig. 4), Grunow adopts the name Fragilaria capucina var. acuta as his own but acknowledges that it is, in part, based on "Fr.[agilaria] acuta Ehr.[enberg] partim?" (Grunow in VAN HeURCK 1881, pl. 45, fig. 4). Later, in the text to the Synopsis, no reference is made to Ehrenberg's name (VAN HEURCK 1885, p. 156), thus one might conclude that Grunow's name Fragilaria capucina var. acuta was intended as a new name rather than a change of rank for Ehrenberg's species. Grunow did not provide any locality details in the plate legend (Grunow in VAN HeURCK 1881, pl. 45, fig. 4) or in the text Van Heurck 1885, p. 156). On the copy of Synopsis des Diatomées de Belgique annotated by Grunow, held in Vienna (W), the illustration for Fragilaria capucina var. acuta is annotated with the following: "Noire Fontaine [Belgium], Delogne [155= Grunow] 2504'). This indicates that these are the type specimens.

It was Rabenhorst, then, who made the first combination of Fragilaria capucina var. acuta (Ehrenberg) Rabenhorst (1864, p. 118), explicitly basing it on Fragilaria acuta Ehrenberg (1840, p. 210) by specifying the illustration in EHrENBERG (1839, taf. II, fig. 10).
Although the description of Fragilaria acuta appeared in 1840 the name was published earlier in Ehrenberg (1839, p. 49). The name appears later in EHRENBERG (1843, pp. 307, 318, 320, 321, 375, 439, 442) and in the illustrations of EHRENBERG (1843, taf. III, fig. IV: 10; taf. III, fig. V: 7) - there are many further illustrations from different localities in EHRENBERG (1854). Analysis of the original drawings made by Ehrenberg (available online on http://download.naturkundemuseum-berlin.de/ Ehrenberg/Ec\%20Drawings/Ec\%20draw\%20001-999/ Ec\%20draw\%20600-699/ECdraw622.jpg) shows that many of these are most likely drawings of valves from a species of Nitzschia, rather than Fragilaria (Van de Vijver, pers. obs.) and thus Ehrenberg's name should not be part of the synonymy of $F$. nevadensis. But because of Rabenhorst's combination, Fragilaria capucina var. acuta Grunow is a nomen. illegit.

Fragilaria nevadensis was recently observed in several Scandinavian samples where it was identified as Fragilaria capucina var. rumpens (LANGE-BERTALOT \& MetZeltin 1996, pl. 7, figs 17-20); however, analysis of the illustrations shows that they also belong to $F$. nevadensis.

It is unclear at this time whether Fragilaria capucina var. mesogongyla, first described by FRENGUELLI (1930, p. 199, fig. 35: 3) from Calama, Chile, is also conspecific with $F$. nevadensis. RIVERA \& CRUCES (2008) studied a population from Rio Lauca (northern Chile) and emended the diagnosis. Two features separate var. mesogongyla from $F$. nevadensis: the valve width of 5-13 $\mu \mathrm{m}$ and the presence of two rimoportulae per valve in the former. Further study of Frenguelli's type material will be necessary to confirm this separation.

This study also shows that Fragilaria sandellii produces longer valves than was indicated in the original description (VAN DE VIJVER et al. 2012, p. 242). The smaller valves of the population observed by Smith in his slide from Jönköping (slide 572) can now be identified as $F$. sandellii. Originally, Smith identified the population as S. parvula Kützing, probably based on the small drawing in KüTZING (1844, plate 14, fig. 1). Kützing described Synedra parvula twice, one based on the freshwater species Frustulia parvula Kützing (KüTZING 1833), which most likely represents a species of Fragilaria, and the other in 1844 from a marine sample collected in Trieste (Italy). The latter was studied by WiLliams \& Round (1986) and transferred to the genus Tabularia as Tabularia parva (Kützing) D.M.Williams et Round. The original material of Frustulia parvula is currently under revision but first results indicate that it is a very small, linear to linear-lanceolate species of Fragilaria, clearly different from the population Smith identified in his slide 572 (VAN DE VIJVER et al., unpubl. res.). Therefore, it is highly unlikely that Smith's original identification can be maintained and the name $F$. sandellii is more appropriate for this population. The observations of the Smith slide showed, however, that the longest valves in $F$. sandellii 
are almost three times as long as the maximum length $(70 \mu \mathrm{m}$ vs. $22 \mu \mathrm{m})$ originally indicated VAN DE VIJVER et al. (2012), whereas the valve width $(4.5-6 \mu \mathrm{m})$ is similar. There is also a slight difference in stria density, as a density of 16-18 striae in $10 \mu \mathrm{m}$ was recorded in the original description. Reanalysis of the type slide resulted, however, in a slightly higher density (18-19 in $10 \mu \mathrm{m})$, which is similar to the density in the Smith slide $(18-20$ in $10 \mu \mathrm{m})$. Valve outline, shape of the apices and shape of the central area and the sternum are similar in both populations.

All Fragilaria taxa discussed in this paper share several features which, therefore, have little diagnostic value (Table 2). All show more or less elongated, linear to linear-lanceolate valves with parallel to convex margins. Fragilaria sandellii has the most convex valves whereas $F$. capucina shows the most linear valves. The valve outline of all other taxa falls between these two extremes. Almost all taxa have slightly to distinctly protracted rostrate to even (sub-)capitate apices with non-protracted, acutely rounded apices only observed in the smaller valves. Morphometrically, all taxa fall within the same range in length $(15-70 \mu \mathrm{m})$, width $(3-5 \mu \mathrm{m})$ and stria density (15-20 in $10 \mu \mathrm{m})$ despite slight, probably non-significant, differences between them. Fragilaria capucina has the lowest stria density (15-16 in $10 \mu \mathrm{m})$ whereas all others usually have $18-20$ striae in $10 \mu \mathrm{m}$.

Despite these important similarities, most taxa can be separated from each other using a combination of other features. It is, however, not possible to indicate one single feature that discriminates all taxa. Careful analysis of a combination of characters will be necessary to positively identify and separate these taxa. Fragilaria capucina always has two rimoportulae per valve, while all other taxa in this paper only possess one per valve. The location of the rimoportulae is important when distinguishing $F$. capucina sensu stricto from a second colony-making $F$. mesolepta sensu lato that can also have two rimoportulae (unpublished information, personal observation, Wetzel) located on the valve mantle instead.

The genus Fragilaria normally has only one rimoportula per valve (WILLIAMS \& Round 1987) although later Tuji \& Williams (2006a, 2006b) modified this genus description to include species with two rimoportulae per valve. There are only a handful of taxa with two rimoportulae per valve including Fragilaria spectra P.D.Almeida, E.Morales et C.E. Wetzel and $F$. tenuissima Lange-Bertalot et Ulrich (LANGE-BERTALOT \& UlRICH 2014; AlmeIDA et al. 2016). The latter two taxa differ, however, from $F$. capucina in having longer, more elongated valves and the absence of colony-formation, a typical feature for $F$. capucina. A second important feature to discriminate these taxa is the formation of long, ribbon-shaped colonies. As can be seen in Table 2, F. capucina and $F$. nevadensis (including $F$. capucina var. acuta and var. acuminata, see above) produce long, ribbon-shaped colonies, whereas, this type of colony has never been observed in the other taxa. The frustules in these colonies are linked to each other using broad, spatulate spines with a flattened, truncated apex. All taxa discussed in this paper possess spines, but linking spines are only observed in the taxa which form colonies. Within the other taxa, the position and shape of the spines vary markedly. Fragilaria battarbeeana has its spines located on the virgae whereas the other three taxa (F. sandellii, F. malouana and F. ennerdalensis) possess spines on the striae, interrupting that way the striae on the valve face from those on the mantle. The spines in F. ennerdalensis are apically elongated, giving them a shark-tooth shape whereas the other taxa form small, thin ( $F$. sandellii) or small, conical (F. malouana, $F$. battarbeeana) spines. A third difference separating these taxa is the shape and structure of the central area. Several of these taxa show ghost striae in their central (F. nevadensis) whereas others only very rarely present these ghost striae (F. malouana, F. battarbeeana).

Apart from confusion with $F$. capucina, the three new taxa most likely have been always confused with smaller valves of $F$. tenera, F. pararumpens, F. radians, $F$. austriaca and even $F$. rumpens, given their elongated, slender outline, relatively high stria density and protracted apices. Fragilaria rumpens and F. pararumpens both form ribbon-shaped colonies, contrary to all three new taxa. Moreover, the central area in both F. rumpens and $F$. pararumpens is larger than in the new taxa, often spanning the entire valve from one margin to the other. The three new taxa always have an asymmetrical central area formed by a unilateral hyaline zone. The central area in F. pararumpens is also clearly swollen but with a distinct constriction on both sides of the inflated central area (see, for instance, LANGE-BERTALOT et al. 2017, plate 9, figs 11-14). Fragilaria tenera is always much longer $(60-120 \mu \mathrm{m})$ with very narrow valves (valve width $<2 \mu \mathrm{m}$ ) in comparison to the three new taxa which are always much wider (minimum valve width $=3 \mu \mathrm{m}$ ). Fragilaria tenera also forms small colonies using linking spines (LANGE-BERTALOT \& ULRICH 2014). Fragilaria radians has a very course striation pattern with only 9-11 striae in $10 \mu \mathrm{m}$, a feature never observed in the new taxa, and hence sufficiently unique to avoid all confusion. The most similar taxa is F. austriaca, a species Grunow described as Synedra austriaca Grunow from Austria in VAN HEURCK (1881). Recently, VAN DE VIJVER et al. (2020a) tried, unsuccessfully, to retrieve the type material of $S$. austriaca. The material was found but no valves of $S$. austriaca could be observed. An epitype was therefore designated based on material from Switzerland. The morphology of the epitype specimens resembles that of the three new taxa but differs nevertheless sufficiently to exclude conspecificity. Fragilaria austriaca always has typically lanceolate valves with clearly convex margins, whereas the three new taxa always show almost linear to slightly linear-lanceolate valves. Similarly to the three new taxa, $F$. austriaca does 
not form ribbon-shaped colonies but instead possesses non-linking spines. However, these spines are always flattened with a shark-tooth tip along the entire spine series (VAN DE VIJVER et al. 2020a, figs 17, 21). Several additional differences include a lower stria density in $F$. austriaca (13-14 in $10 \mu \mathrm{m})$, subcapitate ends and a central area that is always much smaller in $F$. austriaca than in the three new taxa, with often a significant number of ghost striae (VAN DE VIJVER et al. 2020a, fig. 19).

\section{ACKNOWLEDGEMENTS}

The authors wish to thank Prof. Pedro M. Sánchez-Castillo, Dr Salomé F.P. Almeida, Dr Cristina Delgado and Dr Maria Helena Novais for sending us the type material of Fragilaria nevadensis. Sampling on the River Ehen was funded by United Utilities. Jan Krokowski (Scottish Environmental Protection Agency) provided the sample from the River Dee and supporting information. The sampling in Apmeljåkkå was founded by the Swedish Environmental Agency, whereas Viskansbäcken was sampled within the Swedish ISELAW-project (Integrated Studies of the Effects of Liming Acidified Waters). Funding for this research was partly provided to CEW and LE in the framework of the project DIATOMS (LIST - Luxembourg Institute of Science and Technology).

\section{REFERENCES}

Almeida, P.D.; Morales, E.A.; Wetzel, C.E.; Ector, L. \& Bicudo, D.C. (2016): Two new diatoms in the genus Fragilaria Lyngbye (Fragilariophyceae) from tropical reservoirs in Brazil and comparison with type material of $F$. tenera. - Phytotaxa 246: 163-183. DOI: https:// doi.org/10.11646/phytotaxa.246.3.1.

Bey, M.-Y. \& ECTOR, L. (2013): Atlas des diatomées des cours d'eau de la région Rhône-Alpes. Tome 2. Araphidées, Brachyraphidées. - pp. 181-330, Direction régionale de l'Environnement, de l'Aménagement et du Logement Rhône-Alpes, Lyon. http://www.auvergne-rhone-alpes. developpement-durable.gouv.fr/atlas-des-diatomeesa3480.html.

Coles, A.E.; Wetzel, C.E.; Martínez-Carreras, N.; Ector, L.; McDonnell, J.J.; Frentress, J.; Klaus, J.; Hoffmann, L. \& Pfister, L. (2016): Diatoms as a tracer of hydrological connectivity: are they supply limited? - Ecohydrology 9: 631-645. DOI: https:// doi.org/10.1002/eco.1662.

Delgado, C.; Novais, M.H.; Blanco, S. \& Almeida, S.F.P. (2015): Examination and comparison of Fragilaria candidagilae sp. nov. with type material of Fragilaria recapitellata, F. capucina, F. perminuta, F. intermedia and $F$. neointermedia (Fragilariales, Bacillariophyceae). - Phytotaxa 231: 1-18. DOI: https://doi.org/10.11646/ phytotaxa.231.1.1.

Delgado, C.; Novais, M.H.; Blanco, S. \& Almeida, S.F.P. (2016): Fragilaria rinoi sp. nov. (Fragilariales, Fragilariophyceae) from periphytic river samples in Central Portugal. - European Journal of Taxonomy 248: 1-16. DOI : https://doi.org/10.5852/ejt.2016.248.

Desmazières, J.B.H.J. (1830): Plantes Cryptogames du nord de la France. nos 451-500. Lille: issued by the author.

DesmaZIERES, J.B.H.J. (1831): Observations cryptogamiques et zoologiques. Sur quelques-unes des productions qui seront publiées dans le Fascicule X des Plantes cryptogames du nord de la France. - Mémoires de la Société Royale des sciences, de l'agriculture et des arts à Lille, Années 1829 et 1830: 196-210.

EhrenBerG, C.G. (1839): Über das im Jahre 1686 in Curland vom Himmel gefallene Meteorpapier und über dessen Zusammensetzung aus Conferven und Infusorien. - Abhandlungen der Königlichen Akademie der Wissenschaften zu Berlin, Physikalische Klasse 1838: $45-58$.

EhrenBerg, C.G. (1840): Characteristik von 274 neuen Arten von Infusorien. - Bericht über die zur Bekanntmachung geeigneten Verhandlungen der Königlich-Preussischen Akademie der Wissenschaften zu Berlin 1840: 197-219.

EhrenBerG, C.G. (1843): Verbreitung und Einfluss des mikroskopischen Lebens in Süd-und Nord-Amerika. - Abhandlungen der Königlichen Akademie der Wissenschaften zu Berlin 1841: 291-445.

EhrendBerG, C.G. (1854): Mikrogeologie. Einundvierzig Tafeln mit über viertausend grossentheils colorirten Figuren, Gezeichnet vom Verfasser. [Atlas]. - 40 pls, Leopold Voss, Leipzig.

FrenguelLI, J. (1930): Diatomeas contenidas en una muestra de trípoli de Calama, en Chile. - Revista Chilena de Historia Natural 34: 195-199.

Hustedt, F. (1931): Die Kieselalgen Deutschlands, Österreichs und der Schweiz unter Berücksichtigung der übrigen Länder Europas sowie der angrenzenden Meeresgebiete. - In: RaBENHORST, L. (ed.): Kryptogamen Flora von Deutschland, Österreich und der Schweiz. Bd. 7 (Teil 2, Lief. 1). - 176 pp., figs 543-682, Akademische Verlagsgesellschaft Geest \& Portig K.-G., Leipzig.

Kahlert, M.; Kelly, M.G.; Mann, D.G.; Rimet, F.; SATo, S.; Bouchez, A. \& Keck, F. (2019): Connecting the morphological and molecular species concepts to facilitate species identification within the genus Fragilaria (Bacillariophyta). - Journal of Phycology 55: 948-970. DOI: https://doi.org/10.1111/jpy.12886.

KrAmmer, K. \& LANGE-Bertalot, H. (1991): Bacillariophyceae. 3 Teil: Centrales, Fragilariaceae, Eunotiaceae. - In: Ettl, H.; Gerloff, J.; Heynig, H. \& Mollenhauer, D. (eds): Süßwasserflora von Mitteleuropa, Band 2/3. - 576 pp., Gustav Fischer Verlag, Stuttgart - Jena.

Krammer, K. \& Lange-Bertalot, H. (2000): Bacillariophyceae. 3. Teil: Centrales, Fragilariaceae, Eunotiaceae. - In: Ettl, H., Gerloff, J., Heynig, H. \& Mollenhauer, D. (eds): Süßwasserflora von Mitteleuropa Band 2/3 (ed. 2). 599 pp., Spektrum Akademischer Verlag, Heidelberg.

KÜTZING, F.T. (1833): Algarum aquae dulcis germanicarum Decas III. - pp. 1-24, In commissis C.A. Schwetschkii et fil., Halis Saxonum [Halle].

KÜTZING, F.T. (1844): Die kieselschaligen Bacillarien oder Diatomeen. - pp. 1-152, pls. 1-30, Zu finden bei W. Köhne, Nordhausen. DOI: https://doi.org/10.5962/ bhl.title. 64360 .

LANGE-Bertalot, H. (1980): Zur systematischen Bewertung der bandförmigen Kolonien bei Navicula und Fragilaria. Kriterien für die Vereinigung von Synedra (subgen. Synedra) Ehrenberg mit Fragilaria Lyngbye. - Nova Hedwigia 33: 723-787.

Lange-Bertalot, H. \& Metzeltin, D. (1996): OligotrophieIndikatoren. 800 Taxa repräsentativ für drei diverse Seen-Typen. Kalkreich - Oligodystroph - Schwach gepuffertes Weichwasser [Indicators of oligotrophy. 800 taxa representative of three ecologically distinct lake types. Carbonate buffered - Oligodystrophic - Weakly buffered soft water]. - Iconographia Diatomologica 


\section{2: $1-390$.}

Lange-Bertalot, H. \& Ulrich, S. (2014): Contributions to the taxonomy of needle-shaped Fragilaria and Ulnaria species. - Lauterbornia 78: 1-73.

Lange-Bertalot, H.; Hofmann, G.; Werum, M. \& Cantonati, M. (2017): Freshwater Benthic Diatoms of Central Europe: Over 800 Common Species Used in Ecological Assessments. English edition with updated taxonomy and added species. - 942 pp., Koeltz Botanical Books, Schmitten-Oberreifenberg.

Linares-Cuesta, J.E. \& SÁnchez-Castillo, P.M. (2007): Fragilaria nevadensis sp. nov., a new diatom taxon from a high mountain lake in the Sierra Nevada (Granada, Spain). - Diatom Research 22: 127-134. DOI: https:// doi.org/10.1080/0269249X.2007.9705700.

Lohman, K.E. (1957): Cenozoic nonmarine diatoms from the Great Basin. - 190 pp. Unpublished Ph.D. Dissertation, California Institute of Technology, Pasadena, California. Available online at https://thesis.library.caltech. edu/3170/1/Lohman_ke_1957.pdf

Novais, M.H.; Almeida, S.F.P.; Blanco, S. \& Delgado, C. (2019): Morphology and ecology of Fragilaria misarelensis sp. nov. (Bacillariophyta), a new diatom species from southwest of Europe. - Phycologia 58: 128-144. DOI: https://doi.org/10.1080/00318884.20 18.1524245

O'Meara, E. (1875): Report on the Irish Diatomaceae. Part I. - Proceedings of the Royal Irish Academy, Series 2, 2: 235-425. DOI: https://doi.org/10.5962/bhl.title.68743.

Peeters, V. \& Ector, L. (2017): Atlas des diatomées des cours d'eau du territoire bourguignon. Volume 1: Centriques, Araphidées. Direction Régionale de l'Environnement, de l'Aménagement et du Logement Bourgogne-Franche-Comté. - 309 pp. http://www. bourgogne-franche-comte.developpement-durable. gouv.fr/publications-r2759.html

Rabenhorst, L. (1861): Die Algen Europa's. Fortsetzung der Algen Sachsens, Resp. Mittel-Europa's. - Dec. 15-16, Nos 1141-1160, Dresden.

RABENHORST, L. (1864): Flora europaea algarum aquae dulcis et submarinae. Sectio I. Algas diatomaceas complectens, cum figuris generum omnium xylographice impressis. - pp. 1-359. Lipsiae [Leipzig]: Apud Eduardum Kummerum.

RiverA, P.R. \& Cruces, F.L. (2008): Fragilaria capucina Desm. var. mesogongyla Frenguelli, una diatomea presente en la zona norte de la Cordillera de los Andes (Chile), con comentarios sobre la variabilidad del número de procesos labiados en algunos géneros arafidales [Fragilaria capucina Desm. var. mesogongyla Frenguelli, a diatom distributed in northern zone of los Andes mountains (Chile), with comments on the variability of the number of labiate processes in some araphid genera]. - Gayana Botánica 65: 131-138. DOI: https://dx.doi.org/10.4067/S0717-66432008000200002

Rivera-Rondón, C.A. \& Catalan, J. (2017): Diatom diversity in the lakes of the Pyrenees: an iconographic reference. - Limnetica 36: 127-395. DOI: https://dx.doi. org/10.23818/limn.36.10.

Ross, R.; Cox, E.J.; Karayeva, N.I.; Mann, D.G.; Paddock, T.B.B; Simonsen, R. \& Sims, P.A. (1979): An amended terminology for the siliceous components of the diatom cell. - Nova Hedwigia, Beiheft 64: 513-533.

Round, F.E.; Crawford, R.M. \& Mann, D.G. (1990): The Diatoms. Biology \& Morphology of the Genera. -747 pp., Cambridge University Press, Cambridge.

SAYre, G. (1969.): Cryptogamae Exsiccatae - an annotated bibliography of published exsiccatae of algae, lichens, Hepaticae, and Musci. - Memoirs of the New York Botanical Garden 19: 1-179.

Sмith, H.L. (1876-1888): Diatomacearum Species Typicae. Centuries I-VI, numbers 1-600; supplement numbers. - pp. 601-750, Stodder, Boston.

Smith, W. (1856): A synopsis of the British Diatomaceae; with remarks on their structure, functions and distribution; and instructions for collecting and preserving specimens. Vol. 2. - 107 pp., pls 32-62, John van Voorst, London.

Tierno de Figueroa, J.M.; López-Rodríguez, M.J.; Fenoglio, S.; Sánchez-Castillo, P. \& Fochetti, R. (2013): Freshwater biodiversity in the rivers of the Mediterranean Basin. - Hydrobiologia 719: 137-186. DOI: https://doi.org/10.1007/s10750-012-1281-z.

Tus, A. (2007): Type examination of Fragilaria gracilis Østrup (Bacillariophyceae). - Bulletin of the National Museum of Natural Sciences, series B, 33: 9-12.

Tuji, A. \& Williams, D.M. (2006a): Typification of Conferva pectinalis O. F. Müll. (Bacillariophyceae) and the identity of the type of an alleged synonym, Fragilaria capucina Desm. - Taxon 55: 193-199. DOI: https:// doi.org/10.2307/25065541.

Tuji, A. \& Williams, D.M. (2013): Examination of types in the Fragilaria vaucheriae-intermedia species complex. Bulletin of the National Museum of Natural Science, Series B, Botany, 39: 1-9.

Tuji, A. \& Williams, D.M. (2006b): Examination of the type material of Synedra rumpens = Fragilaria rumpens, Bacillariophyceae. - Phycological Research 54: 99-103. DOI: https://doi.org/10.1111/j.1440-1835.2006.00414.x.

Tuji, A. \& Williams, D.M. (2008a): Examination of type material of Fragilaria mesolepta Rabenhorst and two similar, but distinct, taxa. - Diatom Research 23: 503-510. DOI: http://dx.doi.org/10.1080/02692 49X.2008.9705772.

Tuji, A. \& Williams, D.M. (2008b): Examination of types in the Fragilaria pectinalis-capitellata species complex. - In: Likhoshway, Y. (ed.): Proceedings of the Nineteenth International Diatom Symposium. Listvyanka, Irkutsk, Russia, 28th August - 3rd September 2006. - pp. 125-139, Biopress Limited, Bristol.

Turland, N.J.; Wiersema, J.H.; Barrie, F.R.; Greuter, W.; Hawksworth, D.L.; HeRendeEn, P.S.; KNAPP, S.; Kusber, W.-H.; LI, D.-Z.; Marhold, K.; MaY, T.W.; McNeill, J.; Monro, A.M.; Prado, J.; Price, M.J. \& Sмith, G.F., editors (2018): International Code of Nomenclature for algae, fungi, and plants (Shenzhen Code) adopted by the Nineteenth International Botanical Congress Shenzhen, China, July 2017. Regnum Vegetabile, Vol. 159. - pp. [i]-xxxviii, 1-253, Koeltz Botanical Books, Glashütten.

VAn de ViJver, B.; Jarlman, A.; De HaAn, M. \& Ector, L. (2012): New and interesting diatom species (Bacillariophyceae) from Swedish rivers. - Nova Hedwigia 141: 237-253.

VAN DE ViJVER, B. \& ECTOR, L. (2020): Analysis of the type material of Synedra perminuta (Bacillariophyceae) with the description of two new Fragilaria species from Sweden. - Phytotaxa 468: 89-100. DOI: https:// doi.org/10.11646/phytotaxa.468.1.5.

Van de Vijver, B.; Straub, F.; Wetzel, C.E. \& Ector, L. (2020a): Observations on and epitypification of Synedra austriaca Grunow (Fragilariaceae, Bacillariophyta). 
- Notulae Algarum 130: 1-5.

VAn De Vijver, B.; Ector, L.; Schuster, T.M. \& Walter, J. (2020b): Observations on and typification of Synedra gloiophila Grunow (Fragilariaceae, Bacillariophyta) and its transfer to the genus Fragilaria Lyngbye. Notulae Algarum 145: 1-6.

VAn DE ViJVer, B.; Mertens, A. \& ECtor, L. (2020c): Analysis of the type material of Synedra deformis W. Sm. and Synedra vaucheriae var. deformis (Fragilariaceae, Bacillariophyta). - Cryptogamie Algologie 41: 137-149. DOI: https:// doi.org/10.5252/cryptogamie-algologie2020v41a13.

VAN DER WERFF, A. (1955): A new method for cleaning and concentrating diatoms and other organisms. - Internationale Vereinigung für Theoretische und Angewandte Limnologie: Verhandlungen 12: 276-277. DOI: https://doi.org/10. 1080/03680770.1950.11895297.

Van Heurck, H. (1881): Synopsis des Diatomées de Belgique.
Atlas. - pls 31-77, Ducaju et Cie, Anvers.

Van Heurck, H. (1882-1885): Types du Synopsis des Diatomées de Belgique. Déterminations, Notes et Diagnoses par M. A. Grunow. Séries I-XXII [slides Nr. 1-550]. - 118 pp., Édité par l'Auteur, Anvers.

Wetzel, C.E. \& ECTOR, L. (2015): Taxonomy and ecology of Fragilaria microvaucheriae sp. nov. and comparison with the type materials of $F$. uliginosa and $F$. vaucheriae. - Cryptogamie Algologie 36: 271-289. DOI: https:// doi.org/10.7872/crya/v36.iss3.2015.271

Williams, D.M. \& Round, F.E. (1986): Revision of the genus Synedra Ehrenb. - Diatom Research 1: 313-339. DOI: https://doi.org/10.1080/0269249X.1986.9704976.

Williams, D.M. \& Round, F.E. (1987): Revision of the genus Fragilaria. - Diatom Research 2: 267-288. DOI: https:// doi.org/10.1080/0269249X.1987.9705004.

(C) Czech Phycological Society (2021)

Received October 9, 2020

Accepted January 12, 2021 